\title{
In Praise of Arbitrariness: The Proposed 83.7\% Rule of Modified Comparative Fault
}

\author{
William E. Westerbeke*
}

\section{INTRODUCTION}

A century ago the common law doctrine of contributory negligence was the universal rule of tort loss allocation in the various states and territories of the United States. The doctrine completely barred a contributorily negligent plaintiff from any recovery against a negligent defendant. ${ }^{1}$ Criticism of the harshness of the doctrine led first to an array of exceptions designed to ameliorate its harsh results and then to the gradual adoption of comparative fault. ${ }^{2}$ In 1910, Mississippi became the first state to adopt a comparative fault system. ${ }^{3}$ At first, other states were slow to follow Mississippi's lead, but gradually momentum grew; by the end of the century forty-six states, Guam, Puerto Rico, and the Virgin Islands had all adopted some system of comparative fault. ${ }^{4}$ Only

* Professor of Law, University of Kansas School of Law. I would like to thank Jordan Elizabeth Kieffer, class of 2011, for her thorough research and comments.

1. See, e.g., Francis H. Bohlen, Contributory Negligence, 21 HARV. L. REV. 233, 233-34 (1908); Leon Green, Illinois Negligence Law, 39 ILL. L. REV. 36, 36 (1944); Fleming James, Jr., Contributory Negligence, 62 YALE L.J. 691, 691 (1953); Wex S. Malone, The Formative Era of Contributory Negligence, 41 ILL. L. REV. 151, 151-53 (1946); William L. Prosser, Comparative Negligence, 41 CALIF. L. REV. 1, 3-4 (1953).

2. See Brian P. Dunigan \& Jerry J. Phillips, Comparative Fault in Tennessee: Where Are We Going, and Why Are We in This Handbasket?, 67 TenN. L. ReV. 765, 770 (2000); Paul T. Hayden, Butterfield Rides Again: Plaintiff's Negligence as Superseding or Sole Proximate Cause in Systems of Pure Comparative Responsibility, 33 LOY. L.A. L. REV. 887, 888-90 (2000); Joseph W. Little, Eliminating the Fallacies of Comparative Negligence and Proportional Liability, 41 ALA. L. REV. 13, 20-25 (1989); James, supra note 1, at 730-31; Wex S. Malone, Comparative NegligenceLouisiana's Forgotten Heritage, 6 LA. L. REV. 125, 141-42 (1945); Ernest A. Turk, Comparative Negligence on the March, 28 CHI.-KENT L. REV. 189, 203 (1950).

The terms "comparative negligence" and "comparative fault" are used interchangeably in this Article. "Comparative fault" is probably the more accurate description because the substantial majority of states have applied their statutes to some form of fault beyond negligence. For example, many comparative fault states apply comparative fault to strict product liability actions. See VICTOR E. SCHWARTZ, COMPARATIVE NEGLIGENCE § 11.02 (5th ed. 2010).

3. Henry WoOds \& Beth DeERE, Comparative Fault § 1.11 (3d ed. 1996); see Miss. CODE ANN. § 11-7-15 (West 2008).

4. See WoOdS \& DEERE, supra note $3, \S 1.11$. 
Alabama, Maryland, North Carolina, Virginia, and the District of Columbia had failed to adopt any system of comparative fault. ${ }^{5}$

In foreign nations, ${ }^{6}$ in maritime law, ${ }^{7}$ and in the United States at the federal level, ${ }^{8}$ legislatures and courts adopted "pure" comparative fault in which a negligent plaintiff could recover a proportionate fault share of his damages regardless of how great the plaintiff's share of the total fault. The $90 \%$-at-fault plaintiff could recover $10 \%$ of his damages from the 10\%-at-fault defendant. ${ }^{9}$ Among the various states and territories of the United States, only twelve states ${ }^{10}$ and Puerto Rico ${ }^{11}$ have adopted pure comparative fault.

5. See Golden v. McCurry, 392 So. 2d 815, 817 (Ala. 1980) (retaining the contributory negligence rule); Harrison v. Montgomery Cnty. Bd. of Educ., 456 A.2d 894, 905 (Md. 1983) (retaining the contributory negligence rule); Duval v. OM Hospitality, LLC, 651 S.E.2d 261, 264 (N.C. Ct. App. 2007) (applying the contributory negligence rule); Rascher v. Friend, 689 S.E.2d 661, 664-65 (Va. 2010) (applying the contributory negligence rule); Burton v. United States, 668 F. Supp. 2d 86, 107 (D.D.C. 2009) (retaining the contributory negligence rule).

6. See generally Frank E. Maloney, From Contributory to Comparative Negligence: A Needed Law Reform, 11 U. FLA. L. REV. 135, 152-54 (1958) (describing the history and adoption of proportional allocation of loss in negligence cases in several foreign countries); A. Chalmers Mole \& Lyman P. Wilson, A Study of Comparative Negligence, 17 CoRnelL L.Q. 333, 337-38 (1932) (explaining the proportional fault laws of various other countries); Turk, supra note 2, at 230-31 (describing the history and adoption of a proportional division of damages rule by the Brussels Maritime Convention of 1909-10, which was ratified by nearly all important nations).

7. See generally Alfred Huger, The Proportional Damage Rule in Collisions at Sea, 13 CORNELL L.Q. 531 (1928) (sketching the origin and development of the admiralty collision damage rule); Mole \& Wilson, supra note 6, at 339-59 (discussing the proportionate damages rule in admiralty); George C. Sprague, Divided Damages, 6 N.Y.U. L. REV. 15 (1928) (tracing the origin and development of the apportionment rule of damages in admiralty and maritime torts); Turk, supra note 2, at 230-31. The United States Supreme Court judicially adopted pure comparative fault for ship collision cases governed by maritime law in United States v. Reliable Transfer Co., 421 U.S. 397, 411 (1975).

8. See 45 U.S.C. § 53 (2006); 46 U.S.C. § 30304 (2006).

9. See infra notes $81-99$ and accompanying text.

10. Seven states adopted pure comparative fault by judicial decision. See Kaatz v. State, 540 P.2d 1037, 1049 (Alaska 1975); Li v. Yellow Cab Co., 532 P.2d 1226, 1229 (Cal. 1975); Hoffman v. Jones, 280 So. 2d 431, 438 (Fla. 1973); Hilen v. Hays, 673 S.W.2d 713, 719-20 (Ky. 1984); Placek v. City of Sterling Heights, 275 N.W.2d 511, 514 (Mich. 1979); Gustafson v. Benda, 661 S.W.2d 11, 15 (Mo. 1983); Scott v. Rizzo, 634 P.2d 1234, 1242 (N.M. 1981). Five states enacted pure comparative fault by statute. See LA. Civ. CodE ANN. art. 2323 (2010); Miss. CoDE ANN. § 11-7-15 (West 2008); N.Y. C.P.L.R. § 1411 (CONSOL. 1997); R.I. GEN. LAWS ANN. § 9-20-4 (West 2006); WASH. REV. CODE ANN. § 4.22.005 (West 2005). The Michigan legislature subsequently enacted a comparative fault statute that retained pure comparative fault for economic losses but enacted the 50\% rule for non-economic losses. Мich. Comp. LAWS ANN. § 600.2959 (West 2010).

Illinois and Iowa also judicially adopted pure comparative fault. See Alvis v. Ribar, 421 N.E.2d 886, 896-97 (Ill. 1981); Goetzman v. Wichern, 327 N.W.2d 742, 744 (Iowa 1982). The legislature in each state subsequently enacted a statute with the $50 \%$ rule of modified comparative fault. 735 Ill. Comp. StAT. AnN. 5/2-1116(c) (West 2003); IOWA CodE ANN. § 668.3(b) (West 1998 \& Supp. 2010).

11. P.R. LAWS ANN. tit. 31, § 5141 (1991). 
The substantial majority of states plus the Virgin Islands and Guam have adopted a hybrid system of modified comparative fault in which the comparative fault loss allocation ends and the total bar of contributory negligence is reimposed once the plaintiff's fault rises to a certain level. Twenty-one states ${ }^{12}$ and the Virgin Islands ${ }^{13}$ have adopted the so-called $50 \%$ rule system of modified comparative fault. Under this rule, the plaintiff may recover a proportionate fault share of his damages only so long as his fault is "not greater than" the defendant's fault. If the plaintiff's fault exceeds $50 \%$ of the total fault, he is completely barred from any recovery. Twelve states ${ }^{14}$ and Guam ${ }^{15}$ have adopted the socalled $49 \%$ rule system of modified comparative fault. Under this rule, the plaintiff may recover a proportionate fault share of his damages only so long as his fault is "less than" the defendant's fault. The plaintiff who is $49 \%$ at fault may recover $51 \%$ of his damages from the $51 \%$-at-fault defendant, ${ }^{16}$ but he is completely barred from any recovery if both he and the defendant are each $50 \%$ at fault. ${ }^{17}$ One state-South Dakota-has the "slight negligence" system in which the plaintiff may recover a proportionate fault share of his damages only so long as the trier of fact

12. South Carolina adopted the $50 \%$ rule by judicial decision. See Nelson v. Concrete Supply Co., 399 S.E.2d 783, 784 (S.C. 1991). Twenty states enacted the 50\% rule by statute. See ConN. Gen. Stat. AnN. § 52-572h (West 2005); Del. Code AnN. tit. 10, § 8132 (West 2006); HaW. Rev. STAT. § 663-31 (West 2008); 735 ILl. COMP. STAT. ANN. 5/2-1116; IND. CODE ANN. § 34-51-2-6 (West 2011); Iowa CodE ANN. §§ 668.1-668.10 (West 1998 \& Supp. 2010); MASs. GeN. LaWS AnN. ch. 231, § 85 (West 2000); MinN. STAT. AnN. § 604.01 (West 2010); MonT. Code AnN. § 271-702 (2009); NeV. Rev. STAT. ANN. § 41.141 (West 2000); N.H. REV. STAT. ANN. § 507:7-d (2010); N.J. STAT. ANN. § 2A:15-5.1 (West 2000); OHIO ReV. CodE ANN. § 2315.35 (West 2004); OKLA. STAT. ANN. tit. 23, § 13 (West 2008); OR. Rev. StAT. ANN. § 31.60 (West Supp. 2009); 42 Pa. Cons. Stat. Ann. § 7102 (West 2007 \& Supp. 2010); Tex. Civ. Prac. \& Rem. Code AnN. $\S 33.001$ (West 2008); VT. STAT. ANN. tit. 12, § 1036 (West 2007); Wis. STAT. ANN. § 895.045 (West 2006); WYO. STAT. ANN. § 1-1-109 (West 2007).

13. V.I. CoDE ANN. tit. 5, § 1451 (1997).

14. Tennessee and West Virginia adopted the $49 \%$ rule by judicial decision. See McIntyre v. Balentine, 833 S.W.2d 52, 57 (Tenn. 1992) (adopting the 49\% rule); Bradley v. Appalachian Power Co., 256 S.E.2d 879, 883 (W. Va. 1979) (adopting same). Ten states enacted the $49 \%$ rule by statute. ARIZ. Rev. Stat. AnN. § 12-2505 (2003); ARK. Code AnN. § 16-64-122 (West 2004 \& Supp. 2010); Colo. Rev. STAT. ANN. § 13-21-111 (West 2005); GA. CodE ANN. § 51-11-7 (West 2003); IDAHO CoDE ANN. § 6-801 (West 2006); KAN. STAT. ANN. § 60-258a (2005 \& Supp. 2010); ME. Rev. Stat. AnN. tit. 14, § 156 (2003); Neb. Rev. Stat. § 25-21,185.09 (2009); N.D. Cent. CODE ANN. § 32-03.2-02 (West 2008); UTAH CODE ANN. § 78B-5-818 (West 2009).

15. 18 GUAM CODE ANN. § 90108 (2010).

16. See, e.g., Thomas v. Bd. of Twp. Trs. Of Salem Twp., 582 P.2d 271, 273 (Kan. 1978) (finding plaintiff $49 \%$ at fault after jury received instruction on the legal effects of its percentage of fault findings).

17. See, e.g., Affiliated FM Ins. Co. v. Neosho Const. Co., 192 F.R.D. 662 (D. Kan. 2000) (“[I]f plaintiff's fault was 50 per cent or more, Plaintiff will not receive damages." (citing Nail v. Doctor's Bldg., Inc., 708 P.2d 186, 187-89 (Kan. 1985))). 
finds the plaintiff's negligence to be "slight" in comparison to the negligence of the defendant. ${ }^{18}$ The meaning of slight is deemed not capable of precise definition, ${ }^{19}$ and the issue is generally left to the trier of fact. ${ }^{20}$ Apparently, the jury is free to characterize the plaintiff's negligence as slight so long as it is less than the negligence of the defendant. $^{21}$ As with the $49 \%$ rule, the plaintiff is completely barred from any recovery if his negligence is equal to or greater than the defendant's negligence.

Criticism of modified comparative fault is generally divided into two broad categories. First, courts and commentators have criticized modified comparative fault for reviving the harsh bar of contributory negligence, albeit at a higher level, ${ }^{22}$ and producing disproportionate allocation of tort losses. ${ }^{23}$ Dean William Prosser viewed modified comparative fault as merely the result of political compromise. ${ }^{24}$

18. S.D. Codified LAws §§ 20-9-1, 20-9-2 (2004). Both South Dakota and Nebraska originally enacted the "slight-gross" system which allowed plaintiff a comparative fault recovery only when plaintiff's negligence was "slight" in comparison with defendant's "gross" negligence. Otherwise, plaintiff was completely barred by his contributory negligence. See, e.g., Ries v. Daffin Corp., 131 N.W.2d 577, 579 (S.D. 1964) ("Where the evidence... is such that reasonable minds might differ as to the existence of slight negligence on the one hand and gross negligence on the other, the question of comparison is for the jury." (quoting Flanagan v. Slattery, 49 N.W.2d 27, 29 (S.D. 1951))). South Dakota amended its statute in 1964 to eliminate the requirement that defendant's negligence be "gross." S.D. CoDIFIED LAws § 20-9-2. Nebraska amended its statute in 1992 to substitute the $49 \%$ rule in place of the "slight-gross" rule. NEB. REv. STAT. § 25-21,185.09.

19. See Am. State Bank v. List-Mayer, 350 N.W.2d 44, 47 (S.D. 1984) (“[T]he term 'slight' negligence... defies precise definition and prohibits an arbitrary mathematical ratio.” (quoting Crabb v. Wade, 167 N.W.2d 546, 549 (S.D. 1969))).

20. See Schmidt v. Royer, 574 N.W.2d 618, 627 (S.D. 1998) (leaving the issue of contributory negligence to the jury because the facts were in dispute whether "either driver committed negligence more than slight”); cf. Musilek v. Stober, 434 N.W.2d 765, 768 (S.D. 1989) (finding that there was no error in not submitting the issue of what constitutes "slight negligence" to the jury because the court found plaintiff's contributory negligence was more than slight in comparison with that of the defendant).

21. Plaintiff's negligence is to be compared with the negligence of the defendant and not with the conduct of the reasonable prudent person. Schmidt, 574 N.W.2d at 627; Musilek, 434 N.W.2d at 768. "Whether a plaintiff's negligence is slight compared to that of the defendant is a question of fact and varies with the facts and circumstances of each case.” Estate of Largent v. United States, 910 F.2d 497, 499 (8th Cir. 1990) (citing Urban v. Wait’s Supermarket, Inc., 294 N.W.2d 793, 796 (S.D. 1980)).

22. See Dunigan \& Phillips, supra note 2, at 791; see also Li v. Yellow Cab Co., 532 P.2d 1226, 1243 (Cal. 1975); Alvis v. Ribar, 421 N.E.2d 886, 898 (Ill. 1981); Placek v. City of Sterling Heights, 275 N.W.2d 511, 519 (Mich. 1979); Scott v. Rizzo, 634 P.2d 1234, 1241 (N.M. 1981); McIntyre v. Balentine, 833 S.W.2d 52, 57 (Tenn. 1992).

23. See Arthur Best, Impediments to Reasonable Tort Reform: Lessons from the Adoption of Comparative Negligence, 40 IND. L. REV. 1, 7-10 (2007); Maloney, supra note 6, at 169; see also Li, 532 P.2d at 1243; Goetzman v. Wichern, 327 N.W.2d 742, 753-54 (Iowa 1982); Kirby v. Larson, 256 N.W.2d 400, 428 (Mich. 1977); Scott, 634 P.2d at 1241.

24. Prosser, supra note 1, at 25. 
Second, courts and commentators criticized the $49 \%$ rule of modified comparative fault in particular as likely to produce harsh and unexpected results when juries find the parties equally at fault in the expectation of dividing the damage between plaintiff and defendant, only to then discover that the plaintiff was barred from all recovery. ${ }^{25}$

The surprise has always been the relatively limited response to these criticisms. Courts and commentators have suggested two justifications for modified comparative fault. First, it reflects principles of tort loss allocation that evolved under the former all-or-nothing system. ${ }^{26}$ Second, it avoids the problems created by allowing tort claims to be pursued by highly culpable plaintiffs. ${ }^{27}$ Lost in these arguments for and against modified comparative fault is one fairly simple point: the appropriateness of either $49 \%$ or $50 \%$ as the only cutoff points at which comparative fault allocation ends and the complete bar to recovery of contributory negligence is reimposed. Nothing in the literature has explored the possibility of a different-and higher-cutoff point. ${ }^{28}$ While state legislatures have shown remarkable imagination in enacting compromise positions between the extremes of joint and several liability on the one hand and proportionate liability on the other, ${ }^{29}$ only Texas has adoptedand has since repealed-a different cutoff point for modified comparative fault. In actions based on strict tort liability, strict products liability, or breach of warranty, Texas formerly used a $60 \%$ cutoff of comparative fault allocation, ${ }^{30}$ while retaining its $50 \%$ rule for ordinary negligence actions. $^{31}$ All other modified comparative fault states

25. See Dunigan \& Phillips, supra note 2, at 794-95; Stuart F. Schaffer, Comment, Informing the Jury of the Legal Effect of Special Verdict Answers in Comparative Negligence Actions, 1981 DUKE L.J. 824, 830-32.

26. See infra notes $35-44$ and accompanying text.

27. See infra notes $45-54$ and accompanying text.

28. Occasionally commentators make a passing reference to a higher cutoff point as part of another argument, but never in the context of a proposal for adopting such a cutoff point. See, e.g., David C. Sobelsohn, "Pure” vs. "Modified” Comparative Fault: Notes on the Debate, 34 EMORY L.J. 65, 82 n.92 (1985) (asking “[w]hy draw the line at 99\% instead of $90 \%$, 80\%, or 50\%” in response to a suggestion by a proponent of pure comparative fault that a claim by a $99 \%$ at fault plaintiff could be automatically dismissed). The only serious commentary seems to have been an observation by a committee of the Missouri Bar that denial of compensation was unfair in cases of plaintiffs whose fault was determined to be at or above $60 \%$. Norman O. Sanders et al., The Status of Comparative Fault in Missouri, reprinted in SECOND INTERIM REPORT OF THE TORT REVIEW COMMITTEE OF THE MISSOURI BAR TOGETHER WITH RECOMMENDATIONS AND SUPPORTING PAPERS 81, 83 (1986).

29. See infra notes 51-65 and accompanying text.

30. See TEX. Civ. Prac. \& REM. CodE AnN. § 33.001(b) (1987) (amended 1995).

31. See id. § 33.001(a). Michigan has also departed from the norm by adopting a hybrid form of comparative fault in which pure comparative fault governs economic losses while the $50 \%$ rule 
continue to maintain a cutoff point between comparative fault loss allocation and the complete bar of contributory negligence at or just below $50 \%$.

This modest paper will address the possibility of an alternative to the $49 \%$ or $50 \%$ cutoff point. For many years, I have proposed to my firstyear torts students the $83.7 \%$ system of modified comparative fault. In any action in which both plaintiff and defendant were at fault, the loss would be allocated on a comparative fault basis with only two exceptions. First, any plaintiff whose fault exceeded $83.7 \%$ of the total fault would be barred from any recovery. Second, any defendant whose fault exceeded $83.7 \%$ of the total fault would be barred from obtaining any comparative fault reduction of his liability to the plaintiff or any other reduction of his liability based on the fault of another defendant. In short, any party whose fault exceeded $83.7 \%$ bears the full burden of the loss occasioned by the accident.

Invariably students respond that $83.7 \%$ is a completely arbitrary number deserving no credence. I assure them that they are half correct. The number is arbitrary. It could as easily be $68.1 \%$ or $76.9 \%$ or $88.4 \%$. I chose $83.7 \%$ solely because I believe the high cutoff point offers on balance more virtue than sin. The specific number, however, is not the issue. The issue is whether $83.7 \%$ or some comparable number is more or less arbitrary than the $49 \%$ or $50 \%$ number used in all existing modified comparative fault systems. I submit that the $49 \%$ and $50 \%$ numbers are exceedingly arbitrary for at least three reasons. First, they draw a line between parties whose faults are either identical or essentially similar, assigning some to the winners' category and others to the losers' category without any sound reason for the discrimination. ${ }^{32}$ Second, they make equitable loss allocation in most two-party, twoinjury cases virtually impossible. ${ }^{33}$ Third, they force courts to address procedural issues created by or exacerbated by modified comparative fault. $^{34}$

Part II of this Article will discuss whether any existing policies of tort loss allocation support the continued adherence to either the $49 \%$ or $50 \%$ cutoff point. The discussion will focus on (1) the policies and principles developed under the all-or-nothing system and (2) the policies that in the view of some courts or commentators make pure comparative fault an undesirable alternative. Part III will discuss the appropriateness

governs non-economic losses. See Mich. COMP. LAWs ANN. §§ 600.2959 (West 2010).

32. See infra notes $132-35$ and accompanying text.

33. See infra notes $132-35$ and accompanying text.

34. See infra notes $167-83$ and accompanying text. 
of an unusual number as the point at which to cut off comparative fault loss allocation and revert to the complete bar of contributory negligence. A brief examination of seemingly unusual lines drawn by states in limiting the scope of joint and several liability will demonstrate the diverse policy choices that may influence tort loss allocation. Part IV will discuss the affirmative benefits of a significantly higher cutoff point

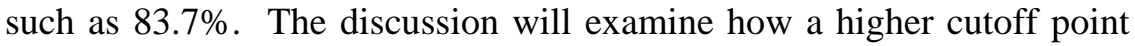
resolves problems concerning (1) the discriminatory effect of a cutoff point drawn between very similar faults, (2) equitable loss allocation in two-party, two-injury actions, and (3) procedures developed to offset the inequitable consequences of the existing modified comparative fault systems. Finally, Part V will discuss the benefits of the two-way provision, which imposes on a highly culpable defendant the entire cost of an accident.

\section{THE LACK OF A PERSUASIVE RATIONALE FOR EXISTING SYSTEMS OF MODIFIED COMPARATIVE FAULT}

The appropriateness of a significantly higher cutoff point between comparative and contributory negligence in part depends on the existence and strength of the justifications for the $49 \%$ and $50 \%$ systems of modified comparative fault. Proponents of the existing systems of modified comparative fault suggest two closely-related justifications. First, the existing systems might be viewed as based upon certain principles carried over from the all-or-nothing system. Second, they might be viewed as necessary to avoid certain problems perceived as inherent in pure comparative fault.

\section{A. Principles of the All-or-Nothing System}

The contributory negligence rule provided that when the contributory negligence of the plaintiff, however slight, combined with the negligence of the defendant to cause injury to the plaintiff, plaintiff's contributory negligence constituted a complete bar to any recovery from the negligent defendant. $^{35}$ The rule originated in 1809 in Butterfield v. Forrester ${ }^{36}$ and dominated English and American tort law until the middle of the twentieth century. ${ }^{37}$ The rule was criticized as harsh because it put on

\footnotetext{
35. See supra note 1.

36. (1809) 103 Eng. Rep. 926 (K.B.) 11 East 60.

37. See generally James, supra note 1; Maloney, supra note 6; Prosser, supra note 1. Much of
} 
one party, the plaintiff, the entire burden of an accident caused by the negligence of both the plaintiff and the defendant. ${ }^{38}$ Moreover, this harshness was exacerbated by the rule's application regardless of how slight the plaintiff's contribution. ${ }^{39}$ Criticism of the harshness of the rule gradually led to a wide array of exceptions in which courts shifted the entire burden of the plaintiff's injury to the defendant. ${ }^{40}$ Thus, the plaintiff recovered all his damages if one of the exceptions applied, but otherwise he recovered nothing. The "all-or-nothing system" is a common reference to this system of tort loss allocation in which the burden of an injury caused by the fault of two or more parties was imposed on just one of those parties rather than shared among them.

Two relevant and closely related principles of the all-or-nothing system governed the selection of which culpable party would bear the entire burden of the injury. The first principle was that when the fault of both plaintiff and defendant was equal, the loss would fall on the plaintiff. This result was consistent with the ancient maxim in pari delicto potior est conditio defendentis, or "in equal fault the position of the defendant is stronger." ${ }^{41}$ Thus, the defendant prevailed and the plaintiff recovered nothing when both of them were negligent ${ }^{42}$ or both were reckless. $^{43}$ No clear rationale for this principle exists, ${ }^{44}$ but in a

the support for the contributory negligence rule may be attributed to the subsequent industrial revolution with its rapid increase in claims by injured factory and railroad workers. See Bohlen, supra note 1, at 254-55; James, supra note 1, at 695; Malone, supra note 1, at 152-55; Prosser, supra note 1 , at $3-4$.

38. See James, supra note 1, at 701 (1953) (“[T] amnesty to a careless defendant every time it administers a deterrent lash to a careless plaintiff ....”); see also Scott v. Rizzo, 634 P.2d 1234, 1241 (N.M. 1981); Turk, supra note 2, at 199-202 (1950).

39. See Hoffman v. Jones, 280 So. 2d 431, 437-38 (Fla. 1973); Turk, supra note 2, at 199-202.

40. See supra note 2 . Some commentators note that it is also unfair to impose the entire burden of an accident on the defendant when the accident was caused by the combined fault of both plaintiff and defendant. See Unif. Comparative Fault Act prefatory note, 12 U.L.A. 121 (2008); Prosser, supra note 1 , at 8 .

41. Under the "in pari delicto" doctrine, relief will be denied "where the parties are shown ... to have acted with the same degree of knowledge as to the illegality of the transaction. The law will leave the parties just in the condition in which it finds them. In such a situation, therefore, the defendant is in the stronger position.” 27A AM. JUR. 2D Equity § 103 (2008). It should be noted that the second "all-or-nothing" principle relevant to this Article has its roots in the stated limitation on the in pari delicto doctrine. "Where the parties appear not to have been in pari delicto, however, the one whose wrong is less than that of the other may be granted relief." Id.

42. See RESTATEMENT (SECOND) OF TORTS § 467 (1965).

43. See id. $\S 482(2)$. Cases on point are exceedingly rare. See, e.g., Harlow v. Connelly, 548 S.W.2d 143, 146 (Ky. Ct. App. 1977); Elliott v. Phila. Transp. Co., 53 A.2d 81, 83 (Pa. 1947). Tennessee courts have held that a plaintiff's gross negligence is a defense to a defendant's gross negligence. See Hood v. Waldrum, 434 S.W.2d 94, 98 (Tenn. Ct. App. 1968); Brown v. Barber, 174 S.W.2d 298, 300 (Tenn. Ct. App. 1943). 
system in which one of two culpable parties will bear the entire burden of a loss, the maxim may serve to provide a starting point or rebuttable presumption that the burden should fall on the plaintiff.

The second principle was that if the burden of loss is to fall entirely on one of two culpable parties, it should preferably fall on the more culpable party. ${ }^{45}$ The contributory negligence rule provided that contributory negligence, however slight, was a complete defense. Positing a lesser fault-no matter how slight—as a complete defense to a greater fault offended a basic sense of fairness, and judicial reaction to this unfairness led to most, if not all, of the many exceptions that over time weakened the contributory negligence rule and eventually set the stage for comparative fault.

The first exceptions provided that plaintiff's contributory negligence would not constitute a defense to categorically greater harms. The traditional categories of tort liability ranging from the highest to the lowest culpability are (1) intentional, (2) willful, wanton, or reckless, (3) negligence, and (4) strict liability. ${ }^{46}$

44. Courts had four choices in how to resolve this issue. First, they could put the entire burden on the plaintiff. The contributory negligence rule reflects this option. Second, they could put the entire burden on the defendant. Workers compensation reflects this option. See Mole \& Wilson, supra note 6, at 604-08. Third, they could divide the loss. For centuries, maritime law followed this option in the ship collision cases. See Turk, supra note 2, at 220-31. See also generally Sprague, supra note 7 , at 15 . Finally, they could apportion the loss in proportion to the fault of the parties. The comparative fault option is now widely followed in the United States and internationally. See supra notes 5-8 and accompanying text.

45. This principle may have its roots in the limitation on the in pari delicto doctrine in situations where one party was less culpable than the other. See supra note 41.

46. See infra Figure 1. Strict liability is placed at the bottom of the figure because technically it involves liability without any fault. The contributory negligence defense to strict liability actions, however, is limited to only that contributory negligence which overlaps assumption of risk. See RESTATEMENT (SECOND) OF TORTS § 402A cmt. n (1965); id. § 524 (1976). The heightened and sometimes unfamiliar dangers associated with those matters deemed appropriate for strict liability may explain the limited contributory negligence defense. The scope of comparative fault defenses to strict liability are beyond the scope of this Article. 
Figure 1: Traditional Categories of Fault

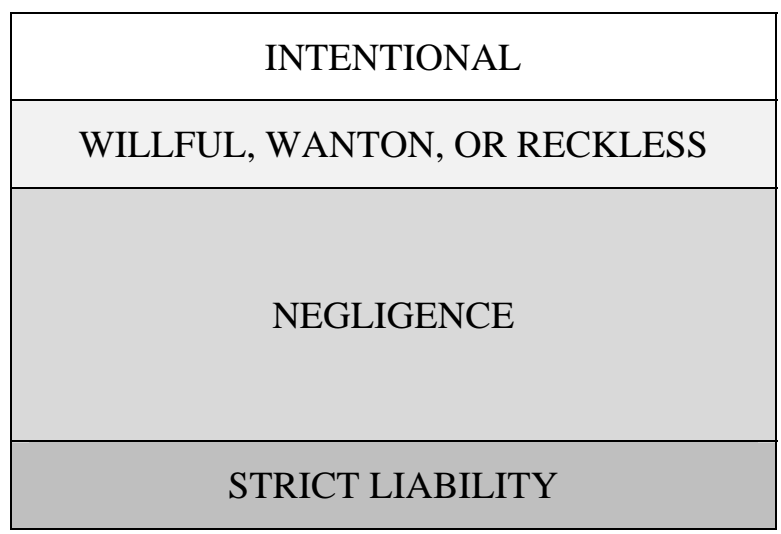

Both intentional misconduct and willful, wanton, or reckless misconduct are considered categorically more culpable than negligence. ${ }^{47}$ Accordingly, contributory negligence is not a defense to a defendant's intentional tort ${ }^{48}$ or to a defendant's willful, wanton, or reckless conduct, ${ }^{49}$ and in each instance, any contributory negligence of the plaintiff is ignored and the entire burden of loss falls on the defendant. Both exceptions involve situations not technically within the basic parameters of the contributory negligence rule because the claim against the defendant is not based on mere negligence but on a different and more culpable category of fault. ${ }^{50}$

The far more challenging problem involved application of this principle within the broad realm of negligence. Conceptually, negligence is negligence, and the pari delicto principle would arguably govern in cases involving a contributorily negligent plaintiff and a

47. See supra Figure 1. Negligence is generally considered conduct that simply falls below the standard of reasonable care-carelessness. See RESTATEMENT (SECOND) OF TORTS § 282 (1965). By contrast, intentional misconduct involves engaging in conduct for the purpose of causing harm or with knowledge that the harm is substantially certain to occur. Id. $\S 8 \mathrm{~A}$. Recklessness is conduct which a reasonable person would realize that not only does it create "an unreasonable risk of physical harm to another, but also that such risk is substantially greater than that which is necessary to make his conduct negligent.” Id. § 500 .

48. See id. § 481.

49. See id. § 482 .

50. See supra note 45 . Occasionally courts have held that willful, wanton, or reckless conduct is merely different in degree from negligence, implying that it is a form of negligence rather than a separate category of fault. See, e.g., Wilby v. Gostel, 578 S.E.2d 796, 801 (Va. 2003). However, the prevailing view is that negligence "does not include conduct recklessly disregardful of an interest of others.” RESTATEMENT (SECOND) OF TORTS § 282 (1965). 
negligent defendant. Yet in a more pragmatic sense, not all negligence is equal. Negligence covers a vast range of human conduct from the highly culpable to the barely culpable. Gradually courts found applications of the second principle wholly within the broad range of negligence and developed at least four categories of exceptions to the contributory negligence rule: (1) categorical disparity based on different subdivisions of negligence; (2) specific situations presumed to involve a disparity in fault; (3) disparity based on defendant's violation of certain safety statutes; and (4) disparity based on situations presumed to involve de minimis fault by plaintiff. The first two exceptions focused on highly culpable conduct by defendants, and the other two focused on minimally culpable conduct by plaintiffs.

First, a few courts experimented with subdividing the broad realm of negligence into "slight" negligence, "ordinary" negligence, and "gross" negligence. " This approach was not the "slight-gross" system of comparative fault adopted in Nebraska and South Dakota. ${ }^{52}$ Rather, it was an all-or-nothing approach in which the burden of loss would shift entirely to the defendant whose gross negligence combined with the plaintiff's "slight" negligence to cause injury. ${ }^{53}$

Figure 2: Categories of Fault with Subdivisions of Negligence

\begin{tabular}{|c|}
\hline INTENTIONAL \\
\hline WILLFUL, WANTON, OR RECKLESS \\
\hline GROSS NEGLIGENCE \\
\hline ORDINARY NEGLIGENCE \\
\hline SLIGHT NEGLIGENCE \\
\hline STRICT LIABILITY \\
\hline
\end{tabular}

51. See infra Figure 2; see also Green, supra note 1, at 45-53; Mole \& Wilson, supra note 6, at 334-36; Prosser, supra note 1, at 17-21.

52. See supra notes $18-21$ and accompanying text.

53. See infra Figure 2. The vastness of the range of conduct capable of being described as negligent made the range of conduct seemingly appropriate for subdivision and thus an extension of the principle that a lesser fault should not constitute a defense to a greater fault. 
Conceptually, the approach was a sound extension of the rule that contributory negligence should not constitute a complete defense to defendant's categorically greater fault. The approach failed, however, because courts could not define "slight," "ordinary," and "gross" negligence with sufficient clarity to prevent endless appeals. ${ }^{54}$

Second, perhaps the best example of a specific situation in which the defendant could be presumed to be consistently and significantly more culpable than the plaintiff is the last clear chance doctrine. ${ }^{55}$ In the classic case, the defendant is aware that his conduct poses a pending danger to the plaintiff, while the plaintiff is either unaware of the danger or no longer able to extricate himself from the danger. If the defendant then fails to exercise reasonable care to prevent injury to the plaintiff, any contributory negligence of the plaintiff is excused and the burden of the loss falls entirely on the defendant. ${ }^{56}$ The disparity in fault justifying the exception arose from the defendant's failure to exercise reasonable care after becoming aware of the danger and thus being the only party with a meaningful opportunity to prevent injury to the plaintiff. The presumed disparity in relative fault is based on the nature of the defendant's conduct as highly culpable, and in many cases, it seems to border on willful, wanton, or reckless conduct. ${ }^{57}$ Little attention is paid

54. See Green, supra note 1, at 50-53; Malone, supra note 2, at 141; Prosser, supra note 1, at 17-18. Dean Green attributed the demise of the system to three problems. First, it was incomplete because it shifted the entire burden of loss to defendant rather than merely mitigating plaintiff's damages. Green, supra note 1, at 48-49. Second, the degrees of negligence approach was simply too confusing and difficult to administer. Id. at 49-50. Third, appellate courts preferred the contributory negligence rule because it gave them greater control over trial courts and juries in determining the outcome of cases. Id. at 50-51.

55. The doctrine had its origin in Davies v. Mann, (1842) 152 Eng. Rep. 588 (Exch.) 10 M. \& W. 546. See Fleming James, Jr., Last Clear Chance: A Transitional Doctrine, 47 YALE L.J. 704, 707 (1938); Malcolm M. MacIntyre, The Rationale of Last Clear Chance, 53 HARV. L. REV. 1225, 1225 (1940).

56. See RESTATEMENT (SECOND) OF TORTS §§ 479-80 (1965).

57. In some cases the defendant failed to exercise reasonable care once he became aware that the plaintiff was in a position of peril and that the plaintiff was unaware of his peril. See, e.g., Peterson v. Burkhalter, 237 P.2d 977, 979-80 (Cal. 1951) (applying the last clear chance doctrine when driver collided with child riding a motor scooter at an intersection because a reasonably prudent driver should have foreseen that the child might not turn or stop at the intersection); Bence v. Teddy’s Taxi, 297 P. 128, 129-30 (Cal. Dist. Ct. App. 1931) (applying the doctrine when a taxi cab struck a pedestrian because the pedestrian was unaware of his dangerous position but the driver had a clear chance to avoid the accident with ordinary care); Fuller v. Illinois Cent. R. Co., 56 So. 783, 789-90 (Miss. 1911) (applying the doctrine when company's train struck a person driving a wagon who could not see the approaching train because the train's driver could see the wagon and could have stopped the train but made no effort to do so); Street v. Calvert, 541 S.W.2d 576, 585 (Tenn. 1976) (applying the doctrine when an unaware pedestrian was struck by a car whose driver could have avoided the accident with ordinary care), abrogated by McIntyre v. Balentine, 833 S.W.2d 52 (Tenn. 1992). When the defendant was aware of plaintiff's peril, the doctrine is 
in the cases to the culpability of the plaintiff in getting into the position of danger in the first place.

Third, a defendant's violation of a routine safety statute, regulation, or ordinance will not normally negate a plaintiff's contributory negligence. $^{58}$ A violation will negate the plaintiff's contributory negligence, however, if the statute, regulation, or ordinance has been "enacted in order to protect a certain class of persons against their own inability to protect themselves." 59 For example, a child's contributory negligence would not be recognized as a defense to a defendant's violation of a statute prohibiting the sale of firearms or explosives to minors $^{60}$ or prohibiting their employment in certain dangerous situations ${ }^{61}$ if those statutes were intended to protect them from their own inexperience and lack of judgment. ${ }^{62}$ In these situations, the defendant is

sometimes called “conscious last clear chance.” Compare Kasanovich v. George, 34 A.2d 523, 524 (Pa. 1943) (involving a trolley car operator who, without ringing a warning bell, ran over a pedestrian walking on the tracks with his back to the trolley), with Davies, 152 Eng. Rep. at 589 (involving a wagon driver who failed to exercise reasonable care to avoid running over a fettered donkey in the road). Kasanovich was decided in plaintiff's favor on the ground that contributory negligence is not a defense to willful, wanton, or reckless conduct, while Davies was decided on grounds that became known as last clear chance. Kasanovich, 34 A.2d at 526; Davies, 152 Eng. Rep. at 590.

The doctrine expanded to cover cases in which the plaintiff was no longer able to extricate himself from a position of peril and the defendant was inattentive and not actually aware of plaintiff's position of peril. See RESTATEMENT (SECOND) OF TORTS $§ 479$ (1965). This latter group of cases, sometimes called "unconscious last clear chance,” lacks a similar disparity of fault because defendant's inattentiveness is ordinary negligence and the level of plaintiff's culpability in getting into the position of peril in the first instance is not considered and not necessarily anything other than ordinary negligence.

58. See RESTATEMENT (SECOND) OF TORTS $§ 483$ (1965). For example, a state statute may prohibit driving a vehicle at an excessive or unreasonable speed, but a defendant's violation of that provision would not excuse a plaintiff from exercising reasonable care for his own safety. Id. § 483 cmt. b.

59. Id. $\S 483 \mathrm{cmt}$. c.

60. See, e.g., Tamiami Gun Shop v. Klein, 116 So. 2d 421, 423-24 (Fla. 1959) (involving the sale of a rifle); Parman v. Lemmon, 244 P. 227, 231-32 (Kan. 1925) (recognizing the rule but declining to include a shotgun within the statutory definition of deadly weapon); see also Zerby v. Warren, 210 N.W.2d 58, 62 (Minn. 1973) (involving the sale of glue to a minor). Contra Zamora v. J. Korber \& Co., 278 P.2d 569, 571 (N.M. 1954) (involving the sale of a rifle).

61. See, e.g., Terry Dairy Co. v. Nalley, 225 S.W. 887, 890 (Ark. 1920); Durden v. Caulkins, 110 So. 2d 39, 41 (Fla. Dist. Ct. App. 1959) (extending the rule to allow recovery for a father who let his under age son drive a motor scooter and sued when another driver hit his son); Louisville, $\mathrm{H}$. \& St. L. Ry. v. Lyons, 159 S.W. 971, 975 (Ky. 1913); Dusha v. Va. \& Rainy Lake Co., 176 N.W. 482, 483 (Minn. 1920); Karpeles v. Heine, 124 N.E. 101, 104 (N.Y. 1919); Lenahan v. Pittston Coal Mining Co., 67 A. 642, 643 (Pa. 1907). Other cases have refused to permit a reduction of damages under comparative fault when child labor laws are violated. See, e.g., Long v. Murnane Assoc., 416 N.Y.S.2d 413 (App. Div. 1979); Strain v. Christians, 483 N.W.2d 783, 789 (S.D. 1992); D.L. v. Huebner, 329 N.W.2d 890, 917-18 (Wis. 1983); Tisdale v. Hasslinger, 255 N.W.2d 314, 315-16 (Wis. 1977).

62. RESTATEMENT (SECOND) OF TORTS § 483 cmts. c, e (1965). 
deemed the more culpable party because of his greater ability to avoid the harm compared to the child plaintiff's relative inability to avoid the harm, and thus the entire burden of loss falls on the defendant.

Finally, courts created exceptions based on circumstances that would tend to support a characterization of the plaintiff's fault as de minimis in nature. Courts recognized that in certain situations the circumstances might make otherwise negligent conduct seem either non-negligent or at worst minimally negligent. Thus, a sudden emergency, a rescue of one in peril, or momentary distraction in the workplace might justify excusing the conduct or characterizing it as non-negligent. For example, as one court noted, "[a]n individual who is injured running into a busy street to say hello to his girl friend should not be under the same standard of care as one injured attempting to assist a toddler who has been struck by a car." ${ }^{63}$ In the same vein, one who makes a poor decision despite adequate time to reflect on a course of action is more culpable than one who makes the same poor decision in an emergency. ${ }^{64}$ One who is working with dangerous machinery to accomplish his employer's needs understandably may not be able to concentrate fully on his own safety. ${ }^{65}$

Some courts completely hide this minimal fault exception behind a substantive rule. For example, many courts once held that children under the age of seven were incapable of negligence. ${ }^{66}$ The rule was in all

63. Bridges v. Bentley, 769 P.2d 635, 640 (Kan. 1989). With respect to a mother rushing into a situation of danger to save her child:

She was not there for a frivolous purpose but to save her child from imminent peril. The law cannot say of her belief that a reasonable person would not have been able to share it. There was little time to deliberate, and there was less time for delay . . . . The mother had to choose at once, in agitation and with imperfect knowledge. Errors of judgment, however, would not count against her if they resulted from the excitement and the confusion of the moment.

Brock v. Peabody Coop. Equity Exch., 352 P.2d 37, 40-41 (Kan. 1960). A rescue attempt will only rise to the level of contributory negligence when the rescuer's conduct is rash. Id. at 39.

64. "[W]here one is confronted through no fault of his own with a sudden emergency, his actions in extremis are not to be judged as they would be in ordinary circumstances." Fruit Indus., Inc. v. Petty, 268 F.2d 391, 394 (5th Cir. 1959) (holding plaintiff driver of car not contributorily negligent in head-on collision with truck that was trying to pass another truck and came over the crest of a hill in plaintiff's lane); see also RESTATEMENT (SECOND) OF TORTS § 296 cmt. b (1965); UNIF. COMPARATIVE FAULT ACT § 2 cmt., 12 U.L.A. 136 (2008) (describing one factor relevant to a party's fault as "the particular circumstances, such as the existence of an emergency requiring a hasty decision”).

65. See Young v. Aro Corp., 111 Cal. Rptr. 535, 537 (Ct. App. 1973) (explaining that when a person's job is especially dangerous, courts may "lessen the amount of caution required of him by law in the exercise of ordinary care”).

66. Most courts have sought to set a minimum age below which a child is presumed incapable of negligence, and about a dozen states set that age at seven. See ProssER AND KEETON ON TORTS $\S 32$ (W. Page Keeton et al. eds., 5th ed. 1984). 
likelihood a mixture of the incapacity and the limited capacity of children to appreciate and avoid dangers. After states adopted comparative fault, courts became more willing to submit to the jury issues of contributory negligence of children four, five, or six years old. ${ }^{67}$ Obviously, children who run out into the street without looking have not suddenly become smarter or more attentive at a younger age. The fault, if any, of these young children was probably presumed to be minor in comparison with the fault of those who were likely to injure them. During the contributory negligence era, young children were protected from the consequences of their possible contributory negligence by the "under seven" presumption. ${ }^{68}$ After comparative fault, the same children were not absolutely protected by the presumption but largely protected by the capacity of the trier of fact under a comparative fault system to attribute to them only a small percentage of the fault. ${ }^{69}$

Clearly, the principle of imposing the entire burden of loss on the more culpable party became well established in the common law before the widespread adoption of comparative fault. As will be seen, some courts and commentators will suggest that the same principle should apply to plaintiffs in modified comparative fault systems. ${ }^{70}$ Yet this principle does not justify the $49 \%$ or $50 \%$ cutoff point in the existing modified comparative fault systems. All of the exceptions to the contributory negligence rule arose in the context of the all-or-nothing system in which the entire burden of a loss caused by two or more culpable parties was imposed on one of them. In that context, it made

67. See, e.g., Honeycutt v. City of Wichita, 796 P.2d 549, 559 (Kan. 1990) (involving a sixyear-old); Toetschinger v. Ihnot, 250 N.W.2d 204, 211 (Minn. 1977) (involving a five-year-old); Lester v. Sayles, 850 S.W.2d 858, 867 (Mo. 1993) (involving a four-year-old); Tenebruso v. Toys “R” Us-NYTEX, Inc., 682 N.Y.S.2d 785, 786 (App. Div. 1998) (involving a four-year-old); Brown v. Smalls, 481 S.E.2d 444, 449-51 (S.C. Ct. App. 1997) (involving a three-year-old); MacConnell v. Hill, 569 S.W.2d 524, 526-27 (Tex. Ct. App. 1978) (involving a six-year-old); Hanson v. Binder, 50 N.W.2d 676, 678 (Wis. 1952) (involving a five-year-old).

Children too young to appreciate and avoid danger are still held incapable of negligence. See, e.g., Marson v. Anctil, 979 F. Supp. 1031, 1038 (D. Vt. 1997) (involving a three-year-old); McFarland v. Indus. Helicopters, Inc., 502 So. 2d 593, 598 (La. Ct. App. 1987) (involving a twoyear-old); Gryc v. Dayton-Hudson Corp., 297 N.W.2d 727, 743 (Minn. 1980) (involving a four-yearold); Rider v. Speaker, 692 N.Y.S.2d 920, 921 (Sup. Ct. 1999) (involving a fourteen-month-old); Strong v. Allen, 768 P.2d 369, 370 (Okla. 1989) (involving a two-year-old); Price v. Kitsap Transit, 856 P.2d 384, 387 (Wash. Ct. App. 1993) (involving a four-year-old).

Despite its adoption of modified comparative fault, Illinois continues to adhere to the "tender years doctrine" that children under the age of seven are incapable of negligence. Appelhans v. McFall, 757 N.E.2d 987, 991 (Ill. Ct. App. 2001) (involving a five-year-old child defendant).

68. See, e.g., Birmingham Ry. Light \& Power Co. v. Jones, 41 So. 146, 146 (Ala. 1906); Ollis v. Houson, E. \& W.T. Ry., 73 S.W. 30, 31 (Tex. Ct. App. 1903).

69. See 65A C.J.S. Negligence § 350 (2010).

70. See infra Part II.B. 
infinite sense to put that burden on the more culpable party rather than on the less culpable party. Once the option of sharing the loss between those parties became available, identifying the less culpable party no longer bore the same importance. The burden could be shared on a proportionate fault basis. The all-or-nothing system required one of two negligent parties to bear a disproportionate burden of loss. Comparative fault does not. The proposed $83.7 \%$ rule does not violate any principle carried over from the all-or-nothing system.

\section{B. Legislative or Judicial Rejection of Pure Comparative Fault}

Pure comparative fault allocates damages in proportion to each party's fault without regard to the extent of the plaintiff's fault. ${ }^{71}$ Plaintiffs who are $60 \%, 70 \%$, or $80 \%$ at fault may recover $40 \%$, $30 \%$, or $20 \%$ of their damages respectively. Pure comparative fault has been widely adopted internationally in civil law and common law countries, in maritime law, in federal legislation in the United States, and in twelve states plus Puerto Rico. ${ }^{72}$ However, the majority of American states have rejected pure comparative fault in favor of one of the three modified systems that limit comparative fault to a plaintiff whose fault is either less or at least not greater than the defendant's fault. ${ }^{73}$

Courts and commentators have offered three criticisms of pure comparative fault. First, critics argue that it will lead to an increase in claims and thus contribute to a rise in insurance premiums, exacerbating the liability insurance crisis. ${ }^{74}$ It would seem axiomatic that if more plaintiffs are allowed to recover, insurance premiums would likely rise. While studies indicate that the adoption of comparative fault in lieu of contributory negligence has had only a negligible impact on claims filed $^{75}$ and on insurance rates, ${ }^{76}$ some slight increase in insurance rates

71. See supra notes 6-11.

72. See supra notes $6-11$.

73. See supra notes $12-21$ and accompanying text.

74. For an excellent and concise coverage of the literature concerning the impact of comparative fault on claims filed and insurance rates, see Carol A. Mutter, Moving to Comparative Negligence in an Era of Tort Reform: Decisions for Tennessee, 57 TENN. L. REV. 199, 237-45 (1990). See also Maloney, supra note 6, at 169-70 (discussing arguments for and against a comparative fault statute).

75. See Maurice Rosenberg, Comparative Negligence in Arkansas: A "Before and After" Survey, 13 ARK. L. REV. 89, 90-93 (1959).

76. See SCHWARTZ, supra note 2, § 22.01[e]. A study of insurance rates in states previously using the contributory negligence rule indicated that the adoption of comparative fault had a minimal impact on insurance rates. Cornelius J. Peck, Comparative Negligence and Automobile Liability Insurance, 58 MiCH. L. REV. 689, 726 (1960). Some commentators concluded that before the formal 
may occur in moving from a modified system to the pure system. ${ }^{77}$ The slight increase is a result of, but not necessarily a problem with, pure comparative fault. As one court noted, "[t]o those who speculate that comparative negligence will cost more money or cause more litigation, we say there are no good economies in an unjust law.,"78

Second, critics argue that disagreement with the specific findings of fault percentages will lead to frequent appeals and thus increased litigation costs. There is, however, no substantial evidence that pure comparative fault has increased litigation costs. ${ }^{79}$ The predicted flood of appeals has not materialized because courts treat jury determinations of fault percentages to be findings of fact subject to minimal judicial review. ${ }^{80}$

The third criticism is that pure comparative fault offends the moral principles underlying the fault system. ${ }^{81}$ To ask a defendant to pay damages to a plaintiff who is more culpable than the defendant undermines the principle of personal responsibility. ${ }^{82}$ In the developmental years of negligence, claims tended to arise from simple accidents between neighbors at a time when accident insurance was unknown. $^{83}$ The notion of personal responsibility reflected the individual's need to look out for himself. ${ }^{84}$ Subsequently, during the industrial period of railroads and factories, "personal responsibility"

adoption of comparative fault, many juries applied a form of comparative fault by reducing a contributorily negligent plaintiff's damages rather than barring him from all recovery. Maloney, supra note 6, at 143-45; Peck, supra, at 726-28. In essence, the adoption of comparative fault was more a change in name than in practice.

77. See Bruce L. Ottley, Comparing Comparative Negligence: Is There a Difference Between the "Pure" and "Modified" Forms?, 22 J. Marshall L. ReV. 243, 254-63 (1988). Professor Ottley studied Illinois jury verdicts rendered in the two-year period before the shift from pure to the $50 \%$ rule of modified comparative fault. Id. His data showed that $51 \%$ of the verdicts found plaintiff under $50 \%$ at fault and an additional $28 \%$ of the jury verdicts found plaintiff equally at fault. Id. Only $21 \%$ of the verdicts found plaintiff more than $50 \%$ at fault, and thus, obviously, the larger number of claims would result in some impact on insurance rates. Id. It is not known how many of those claims found plaintiffs more than $50 \%$ but less than $83.7 \%$ at fault. Id.

78. Hilen v. Hays, 673 S.W.2d 713, 718 (Ky. 1984) (emphasis omitted).

79. See SCHWARTZ, supra note 2, § 22.03[f], [g].

80. See WOODS \& DEERE, supra note 3, § 21.2.

81. See Hayden, supra note 2, at 893-94; Mutter, supra note 74, at 249; Sobelsohn, supra note 28, at 86; John H. Leskera, Comment, Change from "Pure" Comparative Negligence to "Modified" Comparative Negligence-Will It Alleviate the Insurance Crisis?, 32 ST. LOUIS U. L.J. 753, 769 (1988); James D. Ghiardi, Comparative Negligence-The Case Against a Mississippi Type Statute, FOR THE DEFENSE, Oct. 1969, at 61, 64.

82. See Dan B. Dobbs, Accountability and Comparative Fault, 47 LA. L. REV. 939, 943-44 (1987); Ghiardi, supra note 81, at 64.

83. See WoODS \& DEERE, supra note $3, \S 1: 4$.

84. See id. § 1:4; Bohlen, supra note 1, at 253-54; Malone, supra note 2, at 125-26 
became a euphemism to justify favoring industries important to economic growth. ${ }^{85}$ But those industries matured long ago and no longer need protection, and an increased share of negligence litigation involves automobile accidents between two or more individuals. ${ }^{86}$ The suggestion that "personal responsibility" justifies the imposition of a disproportionately large share of accident costs on one of two negligent drivers is simply not persuasive.

Moreover, this criticism is really not based on the inappropriateness of allowing any recovery when the plaintiff is just slightly more at fault than the defendant. One rarely finds expressions of moral outrage when the $45 \%$-at-fault defendant is obligated to pay $55 \%$ of the plaintiff's damages. ${ }^{87}$ A more culpable party sues for and recovers comparative contribution from a less culpable party without any suggestion of moral affront. $^{88}$ Indeed, the United States Supreme Court sensed no moral affront whatsoever when it abandoned the traditional equal division rule in admiralty in favor of pure comparative fault in ship collision cases and allowed a $75 \%$-at-fault ship to maintain an action for $25 \%$ of its damages against the United States. ${ }^{89}$ Rather, the criticism invariably centers on the highly culpable plaintiff suing a minimally culpable defendant for a tiny fraction of the plaintiff's damages. A common example is that of the proverbial 95\%-at-fault plaintiff-the Freddy Krueger of tort lawsuing to recover $5 \%$ of his damages from a virtually innocent defendant. $^{90}$ This result would arguably undermine the moral

85. See WoODS \& DEERE, supra note 3, § 1:5.

86. See John G. Fleming, The Supreme Court of California, 1974-1975-Foreword: Comparative Negligence at Last_By Judicial Choice, 64 CALIF. L. REV. 239, 242 (1976); Malone, supra note 2, at 140-41.

87. In theory, a jury might find it morally offensive to award damages to a plaintiff whose fault was equal to, not less than, a defendant's fault. Mutter, supra note 74, at 257 (suggesting that the $49 \%$ rule coupled with a jury instruction on the legal effect of the percentage of fault findings would enable the jury to decide whether plaintiff deserved partial recovery of damages).

88. See Bielski v. Schulze 114 N.W.2d 105, 106 (Wis. 1962) (allowing a 95\%-at-fault defendant to recover comparative contribution from a 5\%-at-fault tortfeasor), overruled in part by Wangen v. Ford Motor Co., 294 N.W.2d 437 (Wis. 1980); see also ScHWARTZ, supra note 2, $\S 16.02$ (arguing that the $50 \%$ rule "is simply inapplicable among tortfeasors").

89. See United States v. Reliable Transfer Co., 421 U.S. 397, 411 (1975).

90. See Alvis v. Ribar, 421 N.E.2d 886, 897 (Ill. 1981); Tharp v. Bunge Corp., 641 So. 2d 20, 24 (Miss. 1994); McIntyre v. Balentine, 833 S.W.2d 52, 57 (Tenn. 1992); Bradley v. Appalachian Power Co., 256 S.E.2d 879, 883 (W. Va. 1979); Nelson J. Becker, Indiana's Comparative Fault Law: A Legislator's View, 17 IND. L. REV. 881, 881 (1984); Hayden, supra note 2, at 891; Sobelsohn, supra note 28, at 81-82; Leskera, supra note 81, at 769; Legislative Notes, Act 35: An Act to Include Contracts Within the Arkansas Declaratory Judgments Act, 11 ARK. L. REV. 375, 392 (1957). 
underpinnings of tort law generally and the principle of personal responsibility in particular.

However, the 95\%-at-fault plaintiff seems an all too convenient straw man who does not really provide justification for cutting off all plaintiff recovery once the plaintiff's fault reaches $50 \%$ or $51 \%$ of the total. Admittedly, a few such cases have been successfully litigated. ${ }^{91}$ But these cases are rare ${ }^{92}$ and the moral affront posed by these cases may vary. First, these cases are rare because they are simply not economically justified. The overwhelming majority of personal injuries involve relatively modest sums and do not give rise to multi-milliondollar claims. ${ }^{93}$ Trial lawyers take these cases on a contingency fee basis and recover nothing if the claim is unsuccessful. ${ }^{94}$ Assume, for example, a plaintiff is injured in an automobile collision and the trial lawyer takes the case on a $40 \%$ contingency fee basis. After a two day trial, a jury finds the plaintiff $95 \%$ at fault, the defendant $5 \%$ at fault, and total damages at $\$ 25,000 .^{95}$ The plaintiff will receive a judgment for $\$ 1250$, of which he must pay $\$ 500$ to the trial lawyer. The $\$ 500$ will not cover the trial lawyer's overhead and time spent preparing and trying the case. $^{96}$ A trial lawyer who regularly accepts such cases will soon find bankruptcy law to be his new area of concentration.

In addition, a plaintiff assessed $90 \%$ or more of the fault does not necessarily equal a plaintiff whose conduct has been morally

91. See, e.g., Reliance Nat'l Indem. Co. v. Jennings, 189 F.3d 689, 693 (8th Cir. 1999) (involving a plaintiff 97\% at fault); Richard v. Firestone Tire \& Rubber Co., 853 F.2d 1258, 1261 (5th Cir. 1988) (involving a plaintiff 90\% at fault); Cruz v. Union Pac. R.R. Co., 707 P.2d 360, 361 (Colo. App. 1985) (involving a plaintiff 95\% at fault); Blacconeri v. Aguayo, 478 N.E.2d 546, 549 (Ill. App. Ct. 1985) (involving a plaintiff 99\% at fault); Murphy v. Muskegon Cnty., 413 N.W.2d 73, 75 (Mich. Ct. App. 1987) (involving plaintiffs 96\% and 99\% at fault respectively); Dinger v. Dep’t of Natural Res., 383 N.W.2d 606, 607 (Mich. Ct. App. 1986) (involving a plaintiff 95\% at fault); Gaines v. K-Mart Corp., 860 So. 2d 1214, 1215 (Miss. 2003) (involving a plaintiff 95\% at fault); Sutton v. Piasecki Trucking, Inc., 451 N.E.2d 481, 482 (N.Y. 1983) (involving a plaintiff 99\% at fault); Lamborn v. Phillips Pac. Chem. Co., 575 P.2d 215, 220-21 (Wash. 1978) (involving a plaintiff $99 \%$ at fault).

92. See Sanders et al., supra note 28 , at 84.

93. See generally 6 AM. JUR. TRIALS § 21 (1967). A study of 8086 verdicts showed that $61.3 \%$ were plaintiff verdicts and that the mean recovery was in the \$3000 to \$5000 range. Id. § 21 fig. 3.

94. See generally Symposium, Contingency Fee Financing of Litigation in America, Third Annual Clifford Seminar on Tort Law and Social Policy, 47 DEPAUL L. REV. 227 (1998) (discussing the development of the modern contingency fee system and the criticisms of such).

95. In a study of 8086 verdicts, plaintiffs were successful in 4955 cases, or $61.3 \%$, and of the 4955 successful cases, 594 cases produced verdicts of \$25,000 or more. 6 AM. JUR. TRIALS § 21 fig. 3 (1967).

96. See, e.g., Cruz, 707 P.2d at 361 (involving a FELA action in which the plaintiff was $95 \%$ at fault and recovered 5\%, or \$50, from a $\$ 1000$ damage verdict-a $40 \%$ contingency fee would net the attorney \$20). 
reprehensible. Fault is relative. Consider, for example, two separate two car collisions. In the first accident, both drivers may have been driving while highly intoxicated, and a jury may assess their fault to be equal. ${ }^{97}$ The percentage of fault for each is not high because while each of them was highly culpable, their combined fault must add up to $100 \%$. In the second accident, the first driver was trying to make a U-turn on a highway on a foggy night when the second driver, driving slightly too fast for the foggy conditions, collided with the first driver. ${ }^{98}$ The first driver was assessed $90 \%$ of the total fault because, while his conduct was not highly culpable in an absolute sense, it was highly culpable in comparison with the fault of the second driver. Each driver fell only slightly below the standard of reasonable care. Each of them was only slightly at fault in an absolute sense, but the $90 \%$ fault assessed to the first driver reflects the requirement that their fault add up to $100 \% .{ }^{99}$ An actor's percentage of fault reflects how culpable he was only in comparison to the other actor, not how culpable he was in any absolute sense.

Finally, courts and legislatures have less drastic methods of eliminating the claims of the highly culpable plaintiff. Most pure comparative fault states have used the concept of "sole proximate cause" to dismiss the claim of the highly culpable plaintiff. ${ }^{100}$ The European Union is proposing a comparative fault statute that provides that a claim is inappropriate when the defendant's share of the fault is insignificant, and no reduction of the defendant's liability is appropriate when the plaintiff's share of the fault is insignificant. ${ }^{101}$ These devices enable

97. See, e.g., McIntyre v. Balentine, 833 S.W.2d 52, 53 (Tenn. 1992) (stating that plaintiff's blood alcohol level was 0.17 and defendant had consumed alcohol before driving a Peterbilt tractor above the posted speed limit); Dixon v. Stewart, 658 P.2d 591, 592 (Utah 1982) (stating that plaintiff's decedent, a pedestrian, had been smoking marijuana and was found $60 \%$ at fault and defendant driver had a blood alcohol count of $0.09 \%$ and was found $40 \%$ at fault).

98. See, e.g., Miller v. United States ex rel. Dep't of the Army, 901 F.2d 894, 895 (10th Cir. 1990).

99. See Shuey v. Hamilton, 540 P.2d 1122 (Colo. App. 1975); Avery v. Wadlington, 526 P.2d 295 (Colo. App. 1974) (involving a children hit by cars in routine street accidents held to be $70 \%$ at fault); see also Brown v. Keill, 580 P.2d 867 (Kan. 1978) (involving a two-car collision in which one driver was found $90 \%$ at fault and the other $10 \%$ at fault).

100. Hayden, supra note 2, at 945.

101. Principles, Definitions and Model Rules of European Private Law: Draft COMMON FRAME OF REFERENCE (DCFR) INTERIM OUTLINE EDITION (Christian von Bar et al. eds, 2008).

(1) Where the fault of the person suffering the damage contributes to the occurrence or extent of legally relevant damage, reparation is to be reduced according to the degree of such fault.

(2) However, no regard is to be had to 
courts to dismiss the highly culpable plaintiff without necessarily preventing claims by plaintiffs who are not deemed highly culpable but whose fault still exceeds $50 \%$ of the total fault. Furthermore, in some of these cases the jury may drive the point home by assigning $100 \%$ of the fault to the plaintiff. ${ }^{102}$

Finally, courts and commentators have not raised the same concerns about moral affront and judicial economy when a highly culpable defendant seeks to encumber a case and use judicial resources to assert a comparative fault defense against a minimally-at-fault plaintiff. If it is morally irresponsible and a waste of judicial resources for a $90 \%$-at-fault plaintiff to seek to recover $10 \%$ of his damages from a minimally-at-fault defendant, why is it not equally irresponsible and wasteful for a $90 \%$-atfault defendant to seek a $10 \%$ reduction in damages owed to the plaintiff by asserting a comparative fault defense ${ }^{103}$ Concerns about the $95 \%$-atfault plaintiff should not be the tail that wags the dog. They do not justify barring from recovery every plaintiff whose fault slightly exceeds $50 \%$ of the total fault.

In any event, the $83.7 \%$ rule of modified comparative fault is fully sufficient to resolve those concerns. Any plaintiff more than $83.7 \%$ at fault is completely barred from recovery, and any defendant more than $83.7 \%$ at fault is liable for all damages. A party whose fault is $50 \%$ or greater, but does not exceed $83.7 \%$ of the total, would be added to the pool of parties afforded the benefits of comparative fault loss allocation. ${ }^{104}$

(a) an insubstantial fault of the person suffering the damage

(b) fault or accountability whose contribution to the causation of the damage is insubstantial.

Id. This approach is similar to the $83.7 \%$ proposal in the sense that any highly culpable partyplaintiff or defendant-bears the entire burden of the accident and the minimal or "insubstantial" fault of the other party is completely ignored.

102. See Biever v. Williams, 755 S.W.2d 291, 294 (Mo. Ct. App. 1988); Armstrong v. Indus. Elec. \& Equip. Serv., 639 P.2d 81, 82 (N.M. Ct. App. 1981).

103. See, e.g., Wellborn v. Cobray Firearms, Inc., No. 98-8106, 1999 WL 999715, at *1 (10th Cir. Nov. 4, 1999) (finding defendant $90 \%$ at fault and reducing plaintiff's damages by $10 \%$ under Wyoming's comparative fault statute); Norman v. Farrow, 880 So. 2d 557, 561 (Fla. 2004) (finding defendant $90 \%$ at fault and reducing plaintiff's economic and noneconomic damages by $10 \%$ ); Fritscher v. Chateau Golf \& Country Club, 453 So. 2d 964, 974 (La. Ct. App. 1984) (finding defendant $95 \%$ at fault and reducing plaintiff's damages by $5 \%$ ).

104. One commentator has suggested that economic analysis might favor modified comparative fault. See William P. Kratzke, A Case for a Rule of Modified Comparative Negligence, 65 UMKC L. REV. 15, 21 (1996). Economic analysis evaluates legal rules in terms of their cost efficiency. Id. at 19. This issue is beyond the scope of this Article for two reasons. First, the major contributors to economic analysis have not fully agreed on whether traditional contributory negligence or comparative fault is actually more efficient and thus the preferable approach. Compare John Prather Brown, Toward an Economic Theory of Liability, 2 J. LEGAL STUD. 323, 340-46 (1973) (stating that 


\section{THE APPROPRIATENESS OF AN UNUSUAL CUTOFF NUMBER}

Dean Prosser, a strong advocate of pure comparative fault, sought to dismiss modified comparative fault as simply the result of political compromise. ${ }^{105}$ Yet one ought not to dismiss political compromise as an inherently undesirable process in the formulation of judicial rules. Political compromise may well reflect an attempt to accommodate two or more conflicting and legitimate principles or concerns. While I prefer pure comparative fault, I recognize that courts and commentators may have a legitimate concern about highly culpable plaintiffs seeking damages from minimally culpable defendants. ${ }^{106}$ I strongly disagree, however, with the $49 \%$ or $50 \%$ cutoff point used in all modified comparative fault jurisdictions. I am willing to compromise at some number between $49 \%$ and $100 \%$. I open the negotiation with $83.7 \%$.

Admittedly, legislatures have not been overly imaginative in selecting the cutoff point for modified comparative fault. Indeed, only three states ${ }^{107}$ use a number-50\%-as opposed to a generic comparison to define the cutoff point for modified comparative fault. Thus, the statutes permit recovery if the plaintiff's fault is "less than,", "not as

contributory negligence is efficient, but comparative fault is not), and George L. Priest, Modern Tort Law and Its Reform, 22 VAL. U. L. REV. 1, 10-11 (1987) (stating that the movement from contributory negligence to comparative fault has undermined deterrence), with Robert D. Cooter \& Thomas S. Ulen, An Economic Case for Comparative Negligence, 61 N.Y.U. L. REV. 1067, 1070 (1986) (stating that comparative fault tends to minimize the excessive precautions caused by imperfect information), and Daniel Orr, The Superiority of Comparative Negligence: Another Vote, 20 J. LEGAL STUD. 119, 120 (1991) (stating that comparative negligence strengthens incentives for precautions and reduces the likelihood of excess expenditures on them).

Second, the development of economic analysis of tort loss allocation does not seem to have progressed enough to make a persuasive argument for any specific form of modified comparative fault. Professor Kratzke hypothesizes cases in which the defendant has taken some precautions against injury but not enough to constitute reasonable care. Kratzke, supra, at 18. Modified comparative fault would then be appropriate when the additional precautions to prevent injury could be taken more cost effectively by the plaintiff. Assuming Professor Kratzke is correct, his theory does not indicate whether there is a single cutoff point-40\%, $50 \%, 60 \%, 75 \%$, or $83.7 \%$ - that would produce the maximum efficiency or whether there would be one cutoff point that would be appropriate for all cases.

Finally, it is also unclear whether economic analysis would be effective in producing an optimal rule that would apply to two-injury cases such as the two car automobile collision in which both drivers are injured and maintain claims against each other. In short, Professor Kratzke has started a useful discussion, but more is needed before we can conclude how economic analysis might influence the choice of possible modified comparative fault systems.

105. Prosser, supra note 1 , at 25.

106. See supra notes 79-81 and accompanying text.

107. See 735 Ill. Comp. Stat. Ann. 5/2-1116 (West 2003); Tex. Civ. Prac. \& Rem. Code ANN. § 33.001 (West 2008); WYo. STAT. ANN. § 1-1-109(b) (West 2007).

108. KAN. STAT. ANN. § 60-258a(a) (2005 \& Supp. 2010). 
great as," 109 or "not greater than"110 the defendant's fault, or bar recovery if plaintiff's fault is "equal to or exceeds,",111 “equal to or greater than,",112 "greater than," 113 or "as great as.,"114

The treatment of joint and several liability following the widespread adoption of comparative fault demonstrates considerable legislative imagination. A few states retained joint and several liability for multiple negligent defendants. ${ }^{115}$ Other states completely abolished joint and several liability and replaced it with proportionate liability. ${ }^{116}$ However, a substantial minority of states have created various hybrid mixtures of the two approaches, each in an apparent attempt to balance different policy concerns.

Some states draw distinctions based on the type of damage. For example, California, Hawaii, Nebraska, and Ohio retain joint and several liability for economic damages, but impose proportionate liability for non-economic damages. ${ }^{117}$ Illinois retains joint and several liability for past and future medical expenses for any defendant whose fault is not

109. Colo. Rev. Stat. AnN. § 13-21-111(1) (West 2005); Idaho Code AnN. § 6-801 (West 2006).

110. Conn. Gen. Stat. AnN. § 52-572h(b) (West 2005); Del. Code AnN. tit. 10, § 8132 (West 2006); HAW. ReV. STAT. § 663-31(a) (West 2008); MASS. Gen. LAWS ANN. ch. 231, § 85 (West 2000); Minn. Stat. AnN. § 604.01 (West 2010); Mont. Code AnN. § 27-1-702 (2009); Nev. Rev. StAT. ANN. § 41.141(1) (West 2000); N.H. REV. STAT. ANN. § 507:7-d (2010); N.J. STAT. ANN. § 2A:15-5.1 (West 2000); Or. REV. STAT. ANN. § 18.470(1) (West 2003); 42 PA. Cons. STAT. ANN. $\S 7102$ (a) (West 2007 \& Supp. 2010); VT. STAT. ANN. tit. 12, § 1036 (West 2007); Wis. STAT. ANN. $\S$ 895.045(1) (West 2006).

111. ARIZ. REV. STAT. ANN. § 12-2505(A) (2003).

112. NEB. REV. STAT. § 25-21,185.09 (2009).

113. IND. CODE ANN. § 34-51-2-6 (West 2011).

114. N.D. CENT. CODE ANN. § 32-03.2-02 (West 2008).

115. ARK. Code AnN. § 16-64-122 (West 2004 \& Supp. 2010); Del. Code AnN. tit. 10, § 8132 (West 2006); ME. Rev. StAT. AnN. tit. 14, § 156 (2003); 42 PA. Cons. STAT. ANN. § 7102(b.1); R.I. GEN. LAWS ANN. §§ 9-20-4, 9-20-4.1 (West 2006).

116. The abolition of joint and several liability refers to actions in which independent negligent defendants combine to cause a single indivisible injury. All states recognize some exceptions based on specific actions such as intentional torts, concerted action, or certain toxic torts. Some statutes adopt proportionate liability. See, e.g., Alaska Stat. AnN. § 09.17.080 (West 2007); ARIz. Rev. Stat. ANN. § 12-2506; Colo. Rev. STAT. AnN. § 13-21-111.5 (West 2005); ConN. Gen. STAT. ANN. § 52-572h(c) (West 2005); GA. CoDE ANN. § 51-12-33 (West 2003 \& Supp. 2010); IDAHO Code ANN. § 6-803 (West 2006); IND. Code ANN. § 34-51-2-8; KAN. STAT. ANN. § 60-258a(d) (2005 \& Supp. 2010); Ky. Rev. Stat. AnN. § 411.182 (West 2006); Мich. Comp. LAWS AnN. $\S 600.2956$ (West 2010); NEV. Rev. STAT. ANN. § 41.141 (West 2000); N.M. STAT. ANN. § 41-3A-1 (West 2003); N.D. CENT. Code ANN. § 32-03.2-02; Or. Rev. STAT. ANN. § 18.485 (West 2003); Utah Code AnN. § 78B-5-820 (West 2009); Vt. Stat. ANN. tit. 12, § 1036 (West 2007); WASH. REv. Code ANN. § 4.22 .070 (West 2005); WYo. STAT. ANN. § 1-1-109 (West 2007).

117. CAl. Civ. Code § 1431.2 (West 2007); HaW. Rev. Stat. § 663-10.9 (West 2008); NeB. REV. STAT. § 25-21,185.10; OHIO REV. CoDE ANN. § 2315.19 (West 2004). 
less than the plaintiff's fault, and imposes proportionate liability for all other damages. ${ }^{118}$ These statutes reflect the great importance placed on full compensation for economic losses, such as medical costs and lost income, and the lesser importance placed on recovery of soft damages, such as pain and suffering or mental distress. ${ }^{119}$

Other states draw distinctions based on a defendant's share of the total fault. They employ a hybrid approach that blends joint and several liability and proportionate liability in a manner designed to prevent undue burdens on less culpable defendants. Iowa, Missouri, Montana, New Hampshire, Oklahoma, South Carolina, Texas, and Wisconsin limit joint and several liability to defendants whose fault is $50 \%$ or more of the total $^{120}$ or whose fault is more than $50 \%$ of the total. ${ }^{121}$ Other states use variations of the $50 \%$ figure. South Dakota limits joint and several liability to twice a defendant's share of the total fault if the defendant was found to be less than $50 \%$ at fault. ${ }^{122}$ Louisiana imposes several liability but reverts to joint and several liability if the plaintiff is unable to collect $50 \%$ of his damages. ${ }^{123}$

Not all statutes have used $50 \%$ as the cutoff point between joint and several liability and proportionate liability. An earlier version of the Minnesota statute generally held multiple defendants jointly and severally liable but limited the liability of any defendant who is $15 \%$ or less at fault to four times his proportionate fault share of the total damages. ${ }^{124}$ It also limited the liability of any governmental entity less than $35 \%$ at fault to twice its proportionate fault share of the damages. ${ }^{125}$ West Virginia retains joint and several liability generally but limits the liability of any defendant $30 \%$ or less at fault to proportionate liability. ${ }^{126}$

Other states have constructed elaborate frameworks to limit, but not abolish, joint and several liability. New Jersey has a three-tiered

118. 735 Ill. COMP. StAT. ANN. 5/2-1117 (West 2003).

119. This distinction is consistent with the widespread adoption of caps on non-economic damages in tort litigation generally or in medical malpractice litigation specifically. See, e.g., KAN. STAT. ANN. § 60-19a02.

120. IOWA Code ANN. § 668.4 (West 1998 \& Supp. 2010); S.C. CodE AnN. § 15-38-15(A) (Supp. 2010).

121. Mo. AnN. Stat. § 537.067 (West 2008); MonT. CODE ANN. § 27-1-703 (2009); N.H. REV. StAT. AnN. § 507:7-e (2010); OKLA. StAT. AnN. tit. 23, § 15 (West 2008); TEX. CiV. PrAC. \& REM. CODE ANN. § 33.013(b) (West 2008); WIS. STAT. ANN. § 895.045 (West 2006 \& Supp. 2010).

122. S.D. CODIFIED LAWS § 15-8-15.1 (2004).

123. LA. Civ. Code AnN. art. 2324(B) (2010); Touchard v. Williams, 617 So. 2d 885, 892 (La. 1993).

124. MinN. StAT. ANN. § 604.02 (1986) (amended 1988).

125. Id.

126. W. VA. CODE ANN. § 55-7-24 (West 2010). 
approach. It retains joint and several liability fully for any defendant $60 \%$ or more at fault, retains joint and several liability for economic damages and imposes proportionate liability for non-economic damages for any defendant more than $20 \%$ but less than $60 \%$ at fault, and imposes proportionate liability for any defendant $20 \%$ or less at fault. ${ }^{127}$ The former Florida statute had an even more elaborate system in which proportionate liability applied to any defendant $10 \%$ or less at fault and to any defendant less at fault than the plaintiff, and then it incrementally restored joint and several liability for certain types of damage and amounts of damage as a defendant's fault increased from between $10 \%$ and $25 \%$, to between $25 \%$ and $50 \%$, and above $50 \%$. ${ }^{128}$

Joint and several liability had been a basic common law doctrine during the all-or-nothing period. It was supported by a simple, straightforward syllogism - better that a disproportionate burden fall on one of the negligent defendants than on an innocent plaintiff. ${ }^{129}$ If the plaintiff were also negligent, he would be completely barred by the doctrine of contributory negligence. With the adoption of comparative fault, the traditional rationale for joint and several liability no longer existed. While some courts suggested that comparative negligence eliminated joint and several liability, ${ }^{130}$ other courts relied on compensation and causation rationales to retain joint and several liability. ${ }^{131}$ Neither position is completely persuasive, ${ }^{132}$ and the varied compromises in the hybrid statutes may well reflect better solutions. Similarly, an unusual number such as $83.7 \%$ could reflect better balance of plaintiff-defendant loss allocation policy considerations than $49 \%$, $50 \%$, or $100 \%$. Certainly, the variations in the multiple defendant provisions suggest that a novel new cutoff point would not necessarily be inappropriate.

127. N.J. STAT. ANN. § 2A:15-5.3 (West 2000).

128. Fla. StAT. ANN. § 768.81 (1999) (amended 2006).

129. See generally Fowler V. HARPER ET AL., THE LAW OF TORTS $\S 10.1$ (2d ed. 1986) (describing joint tortfeasors and joint and several liability).

130. See, e.g., Miles v. West, 580 P.2d 876, 880 (Kan. 1978) (describing proportionate liability as "the price plaintiffs must pay for being relieved of the burden formerly placed upon them by the complete bar to recovery based on contributory negligence").

131. See, e.g., Coney v. J.L.G. Indus., Inc., 454 N.E.2d 197, 205 (Ill. 1983).

132. The adoption of comparative fault negates the traditional rationale in favor of joint and several liability; it does not provide any affirmative rationale for the abolition of joint and several liability. Conversely, the argument that each negligent defendant has caused the entirety of an indivisible injury does not eliminate the fact that a negligent plaintiff has also caused the entirety of his indivisible injury. 


\section{THE BENEFITS OF THE 83.7\% SYSTEM}

Previously, I suggested that no persuasive policy of tort loss allocation supports cutting off comparative fault allocation and returning to the absolute bar of contributory negligence once the plaintiff's share of the total fault reaches $50 \%$ or $51 \%$. Indeed, a number of advantages flow from the adoption of a significantly higher cutoff point. First and foremost, a higher cutoff point would end an irrational discrimination between parties whose faults are indistinguishable. Second, it would permit a more equitable allocation of loss in two-injury cases in which each of the two actors has a damage claim against the other. Third, it would greatly diminish, and perhaps completely eliminate, the need for a special jury instruction on the legal effect of comparative fault findings. Fourth, a higher cutoff point eliminates the need to choose between the aggregation rule and the separate comparison rule.

\section{A. Equal Treatment of Fundamentally Similar Faults}

The primary benefit of the $83.7 \%$ rule is its elimination of unjustified discrimination between identical or essentially similar faults. The $49 \%$ and $50 \%$ rules of modified comparative fault discriminate between identical or similar faults for no rational reason. ${ }^{133}$ This discrimination flows from a single percentage point in the fault determinations that are admittedly imprecise and unreliable. Under the $49 \%$ rule, a finding of $49 \%$ fault means plaintiff will recover $51 \%$ of his damages while a finding of $50 \%$ fault completely bars him from recovery. Under the $50 \%$ rule, a finding of $50 \%$ fault means plaintiff will recover $50 \%$ of his damages while a finding of $51 \%$ fault completely bars him from recovery. The result of these rules is an irrational and onerous discrimination occurring at the very point at which the fault of the two parties is deemed virtually identical. A higher cutoff point could eliminate much of this discrimination.

\section{The Limitations of Fault Percentages}

For two basic reasons, one should use caution in relying on fault percentages to define the point at which loss allocation reverts from comparative fault back to the complete bar of contributory negligence.

133. None of the principles of the former all-or-nothing system and none of the objections to pure comparative fault justify the $49 \%$ or $50 \%$ cutoff points. See supra Part II.A. 
First, the $49 \%$ and $50 \%$ rules presuppose a mathematical accuracy in determining fault percentages that, in fact, does not exist. Courts and commentators are virtually unanimous that these percentages lack all pretense of mathematical precision. ${ }^{134}$ Determining a party's percentage of fault is simply influenced by too many variables to permit consistency and predictability. ${ }^{135}$

Second, an actor's percentage of fault is not absolute or fixed, but rather relative in comparison with the fault of other actors involved in an injury-producing occurrence. ${ }^{136}$ Thus, a person driving a car under the influence of alcohol may be given a high percentage of fault if the other driver's fault was minor. That same intoxicated driver may be given a more moderate percentage of fault if the other driver committed a similarly serious departure from the standard of care. ${ }^{137}$ In essence, a jury determination that an actor was $50 \%$ at fault in an accident has little meaning by itself. Given their unreliability, fault percentages are justified primarily by the lack of a better alternative to eliminate the cases most likely to constitute nuisance claims by highly culpable plaintiffs. ${ }^{138}$

\section{Higher Cutoff Point Options}

I will concede for sake of argument that fault percentages determined by the trier of fact in a comparative fault action are accurate in the limited sense that they will usually be upheld on appeal and thus are final. ${ }^{139}$ To address the problem of inappropriate discrimination between similar faults, I note that the plaintiff's share of the total fault in the cases progresses along a continuum from less than the defendant's fault to

134. See Kaatz v. State, 540 P.2d 1037, 1048 (Alaska 1975); Ray J. Aiken, Proportioning Comparative Negligence-Problems of Theory and Special Verdict Formulation, 53 MARQ. L. REV. 293, 294-96 (1970); Mutter, supra note 74, at 234; Prosser, supra note 1, at 9; G. Edward White, Tort Reform in the Twentieth Century: An Historical Perspective, 32 VILL. L. REV. 1265, 1285-86 (1987).

135. See Aiken, supra note 134, at 295-96.

136. See id.

137. See, e.g., McIntyre v. Balentine, 833 S.W.2d 52 (Tenn. 1992) (discussing that plaintiffdriver with blood alcohol level of $0.17 \%$ considered $50 \%$ at fault when other driver was speeding with $0.10 \%$ blood alcohol); Dixon v. Stewart, 658 P.2d 591 (Utah 1982) (discussing that driver with blood alcohol level of $0.09 \%$ who pled guilty to negligent homicide found $40 \%$ at fault when decedent who walked out into the highway had been using marijuana).

138. See Mutter, supra note 74, at 231 ("The hallmark of comparative negligence is fidelity to the fault concept and thereby fairness to the litigants.”); see also Aiken, supra note 134, at 295.

139. Courts view the percentages of fault found by the trier of fact as factual findings that are only rarely disturbed on appeal. See supra note 80 and accompanying text. 
equal with the defendant's fault to an even larger share of the total fault. If a legislature should select a higher cutoff point at which comparative fault loss allocation ends and the complete bar of contributory negligence is restored, the question becomes how much of the total fault may be attributed to the plaintiff while still permitting a comparative fault loss allocation.

The most serious problem with the existing systems of modified comparative fault involves the discrimination between parties whose fault was essentially identical. The imprecision of fault findings exacerbates this problem. One cannot demonstrate unequivocally that the faults were, in fact, identical. Indeed, different juries would probably arrive at different assessments of the parties' fault. Assume a two-car collision in which driver $A$ is injured and both driver $A$ and driver $B$ are negligent by reason of essentially identical conduct. Three different juries viewing the same evidence would almost certainly arrive at different allocations of the fault between driver $A$ and driver $B .{ }^{140}$ One might divide the fault $40 \%$ to driver $A$ and $60 \%$ to driver $B$, while the second might divide it equally, and the third might divide it $60 \%$ to $A$ and $40 \%$ to $B$. Under the $49 \%$ rule, driver $A$ would recover $60 \%$ of his damages from the first jury but nothing from the other two. Under the $50 \%$ rule, driver $A$ would recover $60 \%$ of his damages from the first jury, $50 \%$ of his damages from the second, and nothing from the third. In the absence of any identifiable difference in the culpability involved in their conduct or in the moral disappointment attendant to their conduct, these different outcomes are unjustified and morally repugnant. ${ }^{141}$

One solution to this discrimination might be a $60 \%$ rule similar to the former Texas rule in product liability cases. ${ }^{142}$ A $60 \%$ rule would allow any party whose fault is not greater than $60 \%$ to recover a partial recovery. It would avoid the most egregious results of the existing systems of modified comparative fault. In most cases, parties whose

140. See, e.g., Dixon, 658 P.2d at 596 (explaining that the jury initially divided the fault $40 \%$ to plaintiff and $60 \%$ to defendant, but then reconsidered, and allocated the fault $60 \%$ to plaintiff and $40 \%$ to defendant).

141. One eminent scholar addressed the issue succinctly:

To distinguish in an all-or-nothing way between the party, whether plaintiff or defendant, who is deemed forty-five percent negligent and the party who is deemed fifty-five percent negligent is substantially unfair-especially when the relevant judgments are imprecisely and unpredictably rendered after the event by an ad hoc lay jury. The risk of treating basically equal litigants in a dramatically unequal manner is simply too great.

Gary T. Schwartz, Contributory and Comparative Negligence: A Reappraisal, 87 YALE L.J. 697, 727 (1978) (footnote omitted).

142. See supra note 30 and accompanying text. 
fault might seem indistinguishable would be treated equally to partial recovery rather than barring some of them completely from any recovery in a virtually random manner. Most importantly, a 60\% rule would shatter the myth that even under comparative fault it would be morally repugnant to let a more culpable party recover partially from a less culpable party. ${ }^{143}$

While a $60 \%$ rule would constitute an important improvement in loss allocation for parties whose fault seems indistinguishable, the question remains whether a more generous rule would be desirable. For example, a $75 \%$ rule has a certain facial appeal, with comparative fault applicable to parties whose fault does not exceed three-quarters of the total fault. ${ }^{144}$ It was a number used by Dean Prosser in his oft-cited 1953 article on comparative fault:

Obviously any estimate that 40 per cent of the total fault rests with the pedestrian who walks out into the street in the path of an automobile, and 60 per cent with the driver who is not looking and runs him down, represents nothing resembling accuracy based on demonstrable fact. The estimate might quite as well be anywhere between 25-75 and 7525. Yet it is equally clear that a division of the plaintiff's damages on any such basis is at least more accurate than one based on the arbitrary conclusion that 100 per cent of the responsibility rests with the plaintiff and none whatever with the defendant, or ...100 per cent with the defendant and none with the plaintiff-both of which are demonstrably wrong. ${ }^{145}$

In addition, the division of fault was 25-75 in Reliable Transfer, the case in which the United States Supreme Court finally abandoned the equal division rule in favor of pure comparative fault for ship collision cases arising in admiralty. ${ }^{146}$ A 75\% rule would extend comparative fault loss allocation to cases in which the disparity between the parties' culpable conduct is somewhat more pronounced but in which most cases involve only ordinary negligence. ${ }^{147}$

Nevertheless, I would suggest that the cutoff point be raised higher to some point such as $83.7 \%$, which would encompass cases that

143. See supra notes $81-86$ and accompanying text.

144. See Dunigan \& Phillips, supra note 2, at 794 (stating that apportionments of fault in common fractions are "a comfortable way for the jury to divide fault without the difficulty of calculating the precise fault of each party”).

145. Prosser, supra note 1 , at 9 .

146. United States v. Reliable Transfer Co., 421 U.S. 397, 399, 411 (1975).

147. See supra note 51 and accompanying text. 
primarily involve conduct within the broad realm of negligence. ${ }^{148}$ Three points should be noted. First, the discriminatory effect of a single percentage point dictating the difference between partial recovery and total denial of recovery remains wherever the cutoff point is located. Hypothetically, juries could assess $83 \%$ fault and $84 \%$ fault respectively to two plaintiffs who each suffered $\$ 1000$ in damages and whose fault is seemingly identical. The $83 \%$-at-fault plaintiff would recover $\$ 170$, while the 84\%-at-fault plaintiff would be denied recovery of $\$ 160$. These results are simply the inevitable and unfortunate consequences of drawing lines based on mathematically imprecise numbers. Yet the discrimination does not seem particularly inappropriate because the fault of the party who is $84 \%$ at fault is so disproportionate to the party assessed with the remaining $16 \%$.

Second, the higher the cutoff point, the less repugnant the discrimination. The difference between receiving $51 \%$ of one's damages and nothing under the $49 \%$ rule is far harsher than the difference between receiving $17 \%$ of one's damages and nothing under the $83.7 \%$ rule. In the first example, the plaintiff risks considerably more, even though the plaintiff and the defendant seem equally at fault. In the second example, the plaintiff risks much less and his fault is nearly five times greater than the defendant's fault. A complete bar to recovery in the second example is simply not particularly repugnant.

Third, the higher the cutoff point, the greater the concern about nuisance litigation, excessive transaction costs, and judicial economy. Even if pure comparative fault is the most logical approach to loss allocation between two culpable parties, these other factors increasingly enter the equation when the cutoff point becomes very high. The $83.7 \%$ rule will exclude from partial recovery some parties whose fault was merely negligent and not at all aggravated or highly culpable. For example, a child who starts to cross a street without looking for oncoming traffic is in the eyes of most observers negligent but not willful, wanton, or reckless, and yet she might be found $95 \%$ at fault simply because the driver of the car who hit her was barely negligent at all. $^{149}$ Even though her conduct was merely ordinary negligence, denial of her action to recover $5 \%$ of her damages is not necessarily inconsistent

\footnotetext{
148. As previously indicated, I have arbitrarily selected the number 83.7 to symbolize the point at which ordinary negligence would characterize most of the cases included in comparative fault treatment, and aggravated fault or nuisance value would characterize most of the cases excluded from any recovery.

149. See Rangel v. Graybar Elec. Co., 139 Cal. Rptr. 191, 192-93 (Ct. App. 1977) (finding that substantial evidence supported the jury's determination of comparative negligence).
} 
with other values and policies of tort law. But $83.7 \%$ is my suggested cutoff point because it represents the point at which an increasing share of the cases will involve aggravated fault, a risk of nuisance claims, and a risk of wasted judicial resources. ${ }^{150}$

\section{A Short Quiz}

Because this Article had its origin in a classroom exercise, a pop quiz may be appropriate to demonstrate the imprecise nature of comparative fault determinations. Consider the following six accident summaries taken from actual cases and try to guess the share of fault the jury assigned to each party: ${ }^{151}$

No. 1. Defendant is driving north on a two lane highway and turns left to enter a school parking lot. ${ }^{152}$ Plaintiff, driving south at an excessive speed, comes over a slight rise in the road, sees defendant's van turning across the highway in front of him, but cannot stop in time to avoid hitting defendant's van. ${ }^{153}$

No. 2. Defendant was operating a military truck pulling a twentyfour foot trailer on a night when visibility was reduced by thick fog. ${ }^{154}$ Defendant tried to make a U-turn on a two lane highway when plaintiff, a teenage driver traveling slightly too fast for the fog conditions, crashed into defendant's truck. ${ }^{155}$

No. 3. Plaintiff's boat was going across a lake at an excessive speed. ${ }^{156}$ It was a moonless night and visibility was limited. ${ }^{157}$ Suddenly plaintiff's passenger saw a transmission tower in front of him in the middle of the lake, and plaintiff was unable to avoid a collision. ${ }^{158}$ The transmission tower was unlit, although plaintiff was familiar with the lake from prior fishing trips and knew about the existence of the transmission tower. ${ }^{159}$

150. Nobody could demonstrate that $83.7 \%$ is the exact point at which the cases become primarily nuisance cases or aggravated fault cases, but a legislature could pick $83.7 \%$ simply because it would represent a reasonable legislative judgment concerning the appropriate cutoff point.

151. For the answers to this pop quiz see infra note 174.

152. Stokes v. Lundeen, 7 P.3d 586, 588 (Or. Ct. App. 2000).

153. Id.

154. Miller v. United States ex rel. Dep’t of Army, 901 F.2d 894, 895 (10th Cir. 1990).

155. Id. at 895-96.

156. See Woodford v. Carolina Power \& Light Co., 798 F. Supp. 307, 310 (E.D.N.C. 1992) (stating the boat reached a cruising speed of 25 to 30 miles per hour).

157. Id.

158. Id.

159. Id. at 312 . 
No. 4. Defendant was backing a van out of a parking lot across a sidewalk to the street at less than five miles per hour, but the cargo in the rear of the van partially blocked his view. ${ }^{160}$ He hit plaintiff, an eightythree-year-old pedestrian, who was walking along the sidewalk. ${ }^{161}$ Plaintiff did not look carefully to see if any vehicles were coming out of the parking lot. ${ }^{162}$

No. 5. Defendant driver was driving along a city street behind a vehicle that turned. ${ }^{163}$ At that moment, a twelve-year-old boy on his way home from school started to cross the street in the middle of the block rather than at the cross walk at the end of the block. ${ }^{164}$ Defendant did not see him in time to avoid hitting him with his car. ${ }^{165}$

No. 6. Plaintiff's decedent had been smoking marijuana when he started to cross a street at night. ${ }^{166}$ Defendant was driving down the street slightly over the speed limit and with a $0.09 \%$ blood alcohol content. ${ }^{167}$ She saw decedent crossing the street, but when he faltered, she was unable to avoid hitting and killing him. ${ }^{168}$ In a separate criminal action, defendant pled guilty to negligent homicide. ${ }^{169}$

If you scored within five percentage points or less on five or six of the cases, you continue to advocate vigorously for the existing modified comparative fault systems. If you scored within five percentage points or less on two, three, or four of the cases, you may opt for either a $60 \%$ rule or a $75 \%$ rule. If you scored within five percentage points or less on only one or none of the cases, join me in advocating for the $83.7 \%$ rule.

I submit that nothing in these cases justifies barring partial recovery. Each of these accidents is a part of the ongoing carnage on the highway, ${ }^{170}$ and no party is being asked to pay for any amount of damage that he has not in fact caused. With automobile accidents comprising a substantial share of the tort system, a compelling reason should exist for

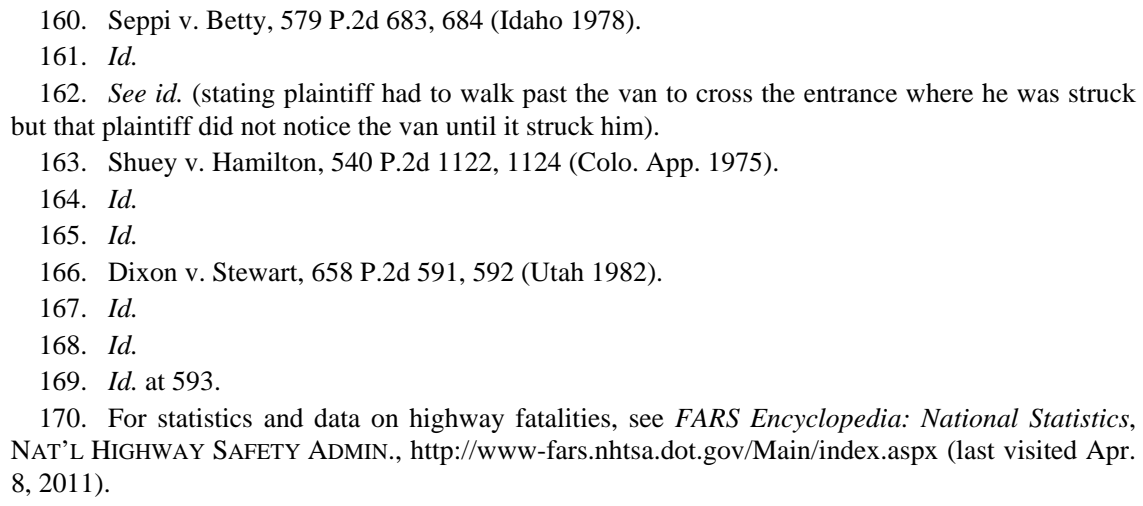


a system that prevents an equitable allocation of loss among the parties. The $83.7 \%$ system would maximize equitable loss allocation in all but those cases that involve conduct undeserving of equitable treatment or such a high share of the total fault as to make them a drain on judicial resources.

\section{B. Equitable Treatment of Two-Injury Accidents}

The second major benefit of the $83.7 \%$ rule is that it enables a relatively equitable allocation of losses in two-injury accidents. The policy of personal responsibility arose out of necessity at an early point in common law development and then continued as part of a broader legal policy of protecting industrial growth. ${ }^{171}$ In the modern era, the focus of tort litigation has shifted considerably to automobile accident litigation, ${ }^{172}$ with a concomitant de-emphasis on personal responsibility. ${ }^{173}$ Moreover, automobile accidents have one feature not often found in the earlier eras-two drivers in an automobile accident, each suffering injury and each initiating a claim against each other. ${ }^{174}$

Under the existing systems of modified comparative fault, an equitable allocation of loss is virtually impossible whenever both parties to an accident are injured and seek to maintain claims for recovery of damages against each other. ${ }^{175}$ The only situation in which both drivers may recover arises under the $50 \%$ rule when the trier of fact allocates

171. See supra notes 85-86 and accompanying text.

172. See Maloney, supra note 6, at 157-58 (explaining how the flood of automobile cases in which plaintiffs are denied recovery because of the contributory negligence rule is evidence that comparative negligence statutes should cover automobile accidents); Schwartz, supra note 141, at 723 (referring to accidents involving motor vehicles as a "major class of accidents").

173. The de-emphasis is not that plaintiffs should be any less vigilant for their own safety. They still have the most to lose in an accident. But with the advent of substantial automobile litigation, both drivers should have the same or very similar obligations of personal responsibility. Both have a great deal to lose in an accident. In the industrial era, the individual plaintiff had a great deal to lose-life or limb—while the corporate defendant usually only risked the loss of money, often insurance money.

174. The answers to the pop quiz in Part IV.A.3.: For question 1, plaintiff $51 \%$ and defendant 49\% at fault. Stokes v. Lundeen, 7 P.3d 586, 590 (Or. Ct. App. 2000). For question 2, plaintiff 10\% and defendant 90\% at fault. Miller v. United States ex rel. Dep’t of Army, 901 F.2d 894, 895 (10th Cir. 1990). For question 3, plaintiff $95 \%$ and defendant $5 \%$ at fault. Woodford v. Carolina Power \& Light Co., 798 F. Supp. 307, 313 (E.D.N.C. 1992). For question 4, plaintiff 50\% and defendant 50\% at fault. Seppi v. Betty, 579 P.2d 683, 684 (Idaho 1978). For question 5, plaintiff $70 \%$ and defendant $30 \%$ at fault. Shuey v. Hamilton, 540 P.2d 1122, 1124 (Colo. App. 1975). For question 6, plaintiff $60 \%$ and defendant $40 \%$ at fault. Dixon, 658 P.2d at 592 .

175. See Unif. Comparative Fault Act prefatory note, 12 U.L.A. 121 (2008); Dunigan \& Phillips, supra note 2, at 795. 
$50 \%$ of the fault to each of them. In that situation, the fault of neither driver is greater than the fault of the other. ${ }^{176}$ Ironically, the same allocation of fault under the $49 \%$ rule results in completely denying any recovery to either of them because neither of them is less at fault than the other. ${ }^{177}$

Under any other allocation of the fault between the two drivers, one driver is by definition less at fault than the other and thus able to recover a proportionate fault share of his damages. The other driver is by definition more at fault and bears a disproportionate share of the total damages - namely, all of his own loss and a portion of the other driver's loss. For example, assume a two-car collision in which driver $A$ is $40 \%$ at fault and driver $B$ is $60 \%$ at fault, and each of them suffered $\$ 100,000$ in damages. Under either rule of modified comparative fault, driver $A$ recovers $60 \%$, or $\$ 60,000$, from driver $B$, while driver $B$ is completely barred from any recovery against driver $A$. Thus, of the total $\$ 200,000$ damages in the accident, driver $A$ caused $\$ 80,000-\$ 40,000$ to driver $B$ and $\$ 40,000$ to himself-and driver $B$ caused $\$ 120,000-\$ 60,000$ to driver $A$ and $\$ 60,000$ to himself. Yet driver $A$ bears a $\$ 40,000$ burdenthe $40 \%$ of his own injuries which are uncollectible, while driver $B$ bears a $\$ 160,000$ burden - the $\$ 60,000$ paid to driver $A$ and $100 \%$ of his own injuries $(\$ 100,000)$ which are uncollectible. ${ }^{178}$

At least two devices exist to temper the harshness of modified comparative fault in two-injury cases. First, a majority of modified comparative fault states permit an instruction to the jury explaining the legal effect of the jury's findings on fault percentages. ${ }^{179}$ Under the $50 \%$ rule, a jury would then appreciate that recovery of partial damages by both drivers is possible only with a $50 \%$ allocation of fault to each driver. The fairness of this adjustment by the jury depends in part on what allocation of fault the jury might have rendered in the absence of such an instruction. Moving their findings from $45 \%$ for one and 55\% for the other to $50 \%$ for each seems to be well within the margin for error and not entirely inappropriate. Moving their findings from 20\% for one and $80 \%$ for the other to $50 \%$ for each seems unfair to the driver initially deemed only $20 \%$ at fault.

\footnotetext{
176. See Unif. Comparative Fault Act prefatory note, 12 U.L.A. 121 (2008); Dunigan \& Phillips, supra note 2, at 795.

177. See Dunigan \& Phillips, supra note 2, at 795.

178. See, e.g., Miles v. West, 580 P.2d 876, 879 (Kan. 1978) (explaining that both drivers injured and fault allocated $40 \%$ to one and $60 \%$ to the other).

179. See infra Part IV.C.
} 
Under the $49 \%$ rule, the instruction on the legal effect of the fault findings can help the plaintiff in a one-injury case in which the jury, aided by the instruction, finds the plaintiff only $49 \%$ at fault as opposed to $50 \%$ or some higher percentage. ${ }^{180}$ However, the instruction can only help one of the two drivers in a two-injury case by allocating the fault $49 \%$ to one and $51 \%$ to the other rather than $50 \%$ to each, thus enabling at least one of them recover.

Second, under the $49 \%$ rule the joinder of a third tortfeasor in the action may enable both drivers to recover a share of their damages. ${ }^{181}$ If the jury allocates $10 \%$ of the fault to the third tortfeasor and $45 \%$ of the fault to each of the two drivers, both drivers can recover $55 \%$ of their damages, $45 \%$ from the other driver and $10 \%$ from the third tortfeasor. If the third tortfeasor is an immune party, ${ }^{182}$ each driver might still recover $45 \%$ of his damages from the other driver. Of course, if the third tortfeasor is only marginally at fault, he could raise concerns about moral affront, nuisance litigation, and the wasteful use of judicial resources.

Under the $83.7 \%$ rule, these problems are almost entirely resolved. In the $40 \%$-at-fault driver $A$ and $60 \%$-at-fault driver $B$ example, each driver would recover a proportionate fault of his own damages and be responsible for a proportionate fault share of the other's damages. Even if instructed about the legal effects of their fault findings, juries will have no reason to distort their findings to achieve what they believe to be a just result. One party or the other will still join additional tortfeasors because a percentage of fault assigned to an additional tortfeasor will usually benefit one or both of the original parties, ${ }^{183}$ but they will not join an additional tortfeasor simply to avoid the negative effects of modified comparative fault. Limited distortion of equitable loss allocation will only occur if one driver's fault exceeds $83.7 \%$. The higher the cutoff point, the more frequently equitable loss allocation will occur in twoinjury cases.

Proponents of modified comparative fault use the two-injury example to demonstrate what they assert is a flaw in pure comparative

180. See Thomas v. Bd. of Trs. of Salem Twp., 582 P.2d 271, 273 (Kan. 1978) (the plaintiff was found $49 \%$ at fault after the jury was given a legal effect instruction).

181. A number of states have provisions in their comparative fault statutes permitting the joinder of additional tortfeasors. See, e.g., Kan. StAT. AnN. § 60-258a(c) (2005 \& Supp. 2010); Mont. CODE ANN. § 27-1-703(4) (2000); UTAH CODE ANN. § 75B-5-818 (West 2009).

182. Some states permit the "joinder" of immune, unknown, or unavailable parties for purposes of allocating fault among all parties contributing to the injury. See, e.g., Brown v. Keill, 580 P.2d 867, 875-76 (Kan. 1978); Mack Trucks, Inc. v. Tackett, 841 So. 2d 1107, 1113-14 (Miss. 2003).

183. An additional tortfeasor's fault will reduce the shares of fault that would otherwise have been assigned to the other parties because the shares of all parties must still add up to $100 \%$. 
fault. They hypothesize a case in which driver $A$ is $75 \%$ at fault and suffers $\$ 100,000$ in damages while driver $B$ is $25 \%$ at fault and suffers $\$ 10,000$ in damages. ${ }^{184}$ Under either pure comparative fault or the proposed $83.7 \%$ rule of modified comparative fault, driver $A$ would recover $\$ 25,000$ from driver $B$, and driver $B$ would recover $\$ 7500$ from driver $A$. They conclude that pure comparative fault violates principles of justice because the more culpable driver will recover a substantially larger amount of damages from the less culpable driver. ${ }^{185}$

The argument seems out of focus. Reduced to its essentials, it is simply an argument that recovery by a plaintiff more at fault than the defendant violates a moral sense of justice. ${ }^{186}$ If driver $B$ were the only party injured in the accident, he would recover still only $\$ 7500$ because that is $75 \%$ of the total damages he suffered. If driver $A$ were the only party injured in the accident, he would still recover $\$ 25,000$ because that is $25 \%$ of the total damages he suffered. Each party pays for the damage he has caused and no more.

\section{Possible Elimination of a Legal Effect Instruction}

A majority of modified comparative fault states mandate or permit the use of special verdicts in comparative fault cases. ${ }^{187}$ The special verdict essentially requires the jury to determine only the percentage of fault of each party and the total damages suffered by a claimant. ${ }^{188}$ In the period prior to the mid-1970s, the virtually unanimous rule was that trial courts would not instruct the jury on the legal effect of their factual determinations. ${ }^{189}$ In theory, this "blindfold" approach let juries make unbiased determinations without favoring one side or the other. ${ }^{190}$ Moreover, it preserved the traditional role of the jury as fact finder and the court as decider of legal issues. ${ }^{191}$ The difficulty with this approach

184. See Sobelsohn, supra note 28, at 88-89; Leskera, supra note 81, at 769.

185. See Sobelsohn, supra note 28, at 88-89; Leskera, supra note 81, at 769.

186. See supra Part II.B.

187. See SCHWARTZ, supra note 2, § 17.04 .

188. See, e.g., KAn. STAT. ANN. § 60-258a(b) (2005 \& Supp. 2010).

189. See Schaffer, supra note 25, at 832. See also generally Leon Green, Blindfolding the Jury, 33 TEX. L. REV. 273 (1955) (discussing arguments for and against the use of special verdicts in Texas courts); Charles Alan Wright, The Use of Special Verdicts in Federal Court, 38 F.R.D. 199 (1966) (discussing arguments for and against the use of special verdicts in the federal courts).

190. See, e.g., Cassia Creek Reservoir Co. v. Harper, 426 P.2d 209, 211-12 (Idaho 1967); McGowan v. Story, 234 N.W.2d 325, 328-30 (Wis. 1975).

191. See Hulmes v. Honda Motor Co., 960 F. Supp. 844, 861 (D.N.J. 1997), aff'd, 141 F.3d 1154 (3d Cir. 1998); Wheeler v. Bagley, 575 N.W.2d 616, 619 (Neb. 1998); McGowan, 234 N.W.2d at 
was the tendency to produce harsh and unintended results. A jury might allocate the fault evenly between plaintiff and defendant, believing that the plaintiff would receive half his damages, only to discover that under the $49 \%$ rule the plaintiff was completely barred from recovery. ${ }^{192}$

The response was to authorize or mandate a special instruction to inform the jury of the legal effects of its comparative fault fact findings. ${ }^{193}$ Courts offered three related reasons for rejecting the rule against such an instruction. First, the rule would be futile because intelligent jurors and jurors who have participated in prior trials will often have some knowledge of the legal effects of their comparative fault findings. ${ }^{194}$ Second, the rule would cause juries to speculate unnecessarily on the meaning of their comparative fault findings, often leading to mistaken and unintended results. ${ }^{195}$ Third, the rule is an unwarranted intrusion on the traditional role of the jury to temper harsh rules of law and produce substantial justice for the parties. ${ }^{196}$

Today a majority of modified comparative fault states authorize or mandate an instruction on the legal effect of the jury's comparative fault findings. ${ }^{197}$ In some states the instruction is mandated either by statute ${ }^{198}$ or by judicial decision, ${ }^{199}$ and it is reversible error not to give the instruction even if a party did not request it. ${ }^{200}$ Other states require a

329. But see Dixon v. Stewart, 658 P.2d 591, 594 (Utah 1992) (noting that “[c]ommentators who view the jurors as ignorant and emotional anachronisms in modern courts are naturally in favor of strict a separation between the fact-finding function of the jury and the application of law by the court”).

192. See, e.g., Seppi v. Betty, 579 P.2d 683, 690 (Idaho 1978); Adkins v. Whitten, 297 S.E.2d 881, 883 (W. Va. 1982).

193. See generally SCHWARTZ, supra note 2, § 17.05 .

194. See, e.g., Kaeo v. Davis, 719 P.2d 387, 396 (Haw. 1986); Thomas v. Bd. of Trs. of Salem Twp., 582 P.2d 271, 280 (Kan. 1978); Sollin v. Wangler, 627 N.W.2d 159, 163-64 (N.D. 2001).

195. See, e.g., Seppi, 579 P.2d at 690; Dilaveris v. W.T. Rich. Co., 673 N.E.2d 562, 566 (Mass. 1996); DeCelles v. State ex rel. Dep’t of Highways, 795 P.2d 419, 421 (Mont. 1990); Sollin, 627 N.W.2d at 164-65.

196. See, e.g., Porche v. Gulf Miss. Marine Corp., 390 F. Supp. 624, 632 (E.D. La. 1975); Thomas, 582 P.2d at 280. But see Brodsky v. Grinnell Haulers, Inc., 853 A.2d 940, 951 (N.J. 2004).

197. Some empirical research suggests that plaintiffs recover more often but recover smaller verdicts when the jury is not blindfolded. Jordan H. Leibman et al., Blindfolding Comparative Fault Juries on Percentage of Negligence: Should Indiana Follow Lead of Illinois?, 41 RES GESTAE, May 1988, at 24, 29-30.

198. See, e.g., CONN. Gen. STAT. AnN. § 52-572h (West 2005); IOWA CodE ANN. § 668.3(5) (West 1998); Neb. REV. StAT. § 25-21,185.09 (2009); Or. REV. Stat. AnN. § 31.605(2) (West Supp. 2009).

199. See, e.g., Cook v. Doty, 608 P.2d 1028, 1029-30 (Kan. Ct. App. 1980); McIntyre v. Balentine, 833 S.W.2d 52, 57 (Tenn. 1992).

200. See Nail v. Doctor's Bldg., Inc., 708 P.2d 186, 189 (Kan. 1985); see also Wheeler v. Bagley, 575 N.W.2d 616, 620-21 (Neb. 1998) (explaining that failure to instruct jury on reduction of damages by percentage of plaintiff's fault is reversible error). 
party to request the instruction but treat as reversible error failure to give the instruction when requested. ${ }^{201}$ Finally, a number of states permit the instruction but treat the issue as within the trial court's discretion and recognize that the instruction might not be appropriate in some cases. ${ }^{202}$ In a few states, attorneys may discuss with the jury in closing argument the meaning and application of the special instruction. ${ }^{203}$

The special instruction is most compelling in states having the $49 \%$ rule or the separate comparison rule. Both of these rules are likely to produce harsh results that the jury did not contemplate nor intend. ${ }^{204}$ The same might be said of states having the $50 \%$ rule in which the jury would expect a plaintiff found to be $55 \%$ at fault to recover $45 \%$ of his damages. The concern about harsh or unintended results diminishes as the comparative fault system tolerates a higher percentage of plaintiff fault. Under the proposed $83.7 \%$ rule of modified comparative fault, the need for a special instruction is really de minimis. A real sense of unfairness arises in cases in which the jury, unaware of the legal effect of the state's $49 \%$ rule, found the plaintiff and the defendant each $50 \%$ at fault. Comparative fault findings are rough approximations, and no piece of "factual" evidence exists that would lead a jury to find the plaintiff only $49 \%$ at fault. The $49 \%$ rule is truly a "booby trap for the unwary." 205 By contrast, little sense of unfairness would arise if a jury-

201. See, e.g., Wyo. Stat. AnN. § 1-1-109(b) (West 2007); Martel v. Mont. Power Co., 752 P.2d 140, 145-46 (Mont. 1988).

202. See, e.g., Seppi v. Betty, 579 P.2d 683, 692 (Idaho 1978); Flood v. Southland Corp., 601 N.E.2d 23, 30-31 (Mass. App. Ct. 1992), aff'd, 616 N.E.2d 1068 (Mass. 1992); Sollin v. Wangler, 627 N.W.2d 159, 165 (N.D. 2001); Dixon v. Stewart, 658 P.2d 591, 596-97 (Utah 1982).

203. See Iowa Code AnN. § 668.3(5) (West 1998); MinN. R. Civ. P. 49.01(b). Despite having discretion, the trial court may commit reversible error by failing to instruct the jury on legal effect when jury questions during deliberations indicate jury confusion. See, e.g., Rapoza v. Parnell, 924 P.2d 572, 579 (Haw. Ct. App. 1996).

204. It is not the purpose of this Article to resolve the propriety of the legal effects instruction. On one side, the instruction could be viewed as encouraging low-level jury nullification by informing the jury how to thwart the will of the legislature. In addition, the instruction opens the door for a never-ending list of other legal effect instructions. See, e.g., Kaeo v. Davis, 719 P.2d 387, 396 (Haw. 1986) (informing jury about joint and several liability); Le'Gall v. Lewis Cnty., 923 P.2d 427, 430 (Idaho 1996) (informing jury that an individual on the special verdict form is not a party to the action). On the other hand, the instruction may be viewed as cautioning the jury against a hasty and convenient $50 \%-50 \%$ allocation without careful examination of all the evidence. See, e.g., Seppi, 579 P.2d at 690. I prefer to view it as that rare case in which two wrongs- the $49 \%$ rule and the legal effect instruction-make a right.

205. This phrase was used to describe the harsh and unexpected effect of the commercial law requirement of notice in product liability personal injury claims. Greenman v. Yuba Power Prods., Inc., 377 P.2d 897, 900 (Cal. 1963). The description is equally applicable to the $49 \%$ rule of modified comparative fault. 
not instructed on the legal effects of the $83.7 \%$ rule-found a plaintiff $85 \%$ at fault and then discovered that the plaintiff would recover nothing.

\section{Elimination of the Aggregation Versus Separate Comparison Issue}

In cases involving a single plaintiff and a single defendant, the application of modified comparative fault is straightforward. If the plaintiff's fault does not exceed the $49 \%$ or $50 \%$ cutoff point, the plaintiff recovers damages reduced in proportion to his fault. If the plaintiff is $40 \%$ at fault and suffered $\$ 100,000$ in total damages, he recovers $\$ 60,000$. Change the case, however, by adding a second defendant, making each defendant now $30 \%$ at fault. If the single comparison rule is adopted and the plaintiff's $40 \%$ fault is compared against each defendant separately, the plaintiff is completely barred from recovery because his $40 \%$ fault is greater than, not equal to or less than, each defendant's $30 \%$ fault. If the aggregation rule is adopted and the plaintiff's $40 \%$ fault is compared against the $60 \%$ aggregate fault of the defendants, the plaintiff recovers $\$ 60,000$. The substantial majority of modified comparative fault states have adopted the aggregation rule. ${ }^{206}$ Only three states follow the single comparison rule. ${ }^{207}$

The choice between these two rules afforded courts one of their better opportunities to develop and explain a rationale for the $49 \%$ or $50 \%$ cutoff point in modified comparative fault. Unfortunately, in most states, the statutory language enabled the issue to be decided purely on the rules of statutory construction and interpretation. The aggregation rule was clearly intended by legislatures that provided for a comparison of the plaintiff's fault with the "combined negligence"208 or the "aggregate negligence" 209 of parties against whom recovery is sought or

206. See SCHWARTZ, supra note 2, § 3.05[c][1].

207. Idaho, Minnesota, and Wisconsin follow the single comparison rule, and each of them has a comparative fault statute that calls for comparison of the plaintiff's fault with the fault of "the person” against whom recovery is sought. IDAHO CODE ANN. § 6-801 (West 2006); MinN. STAT. ANN. § 604.01 (West 2010); WIS. STAT. ANN. § 895.045 (West 2006).

208. See, e.g., Conn. Gen. Stat. AnN. § 52-572h(b) (West 2005); Del. Code AnN. tit. 10, § 8132 (West 2006); IowA Code ANN. § 668.3(1)(b) (West 1998 \& Supp. 2010) ("combined percentage of fault”); MONT. CODE ANN. § 27-1-702 (2009); N.J. STAT. ANN. § 2A:15-5.1 (West 2000); N.D. CEnT. Code ANn. § 32-03.2-02 (West 2008); OHIo Rev. Code AnN. § 2315.35 (West 2004); OKLA. Stat. AnN. tit. 23, § 13 (West 2008); OR. Rev. Stat. AnN. § 31.600 (West Supp. 2009).

209. See, e.g., HAW. Rev. STAT. § 663-31(a) (West 2008); Mich. CoMP. LAWS ANN. § 600.2959 (West 2010); see also MASs. GEN. LAWS ANN. ch. 231, § 85 (West 2000) ("total amount of negligence” of the persons against whom recovery is sought); NEB. REV. STAT. § 25-21,185.09 (2009) (“total negligence of all persons”); VT. STAT. ANN. tit. 12, § 1036 (West 2007) ("total 
with the negligence or fault of the "party or parties"210 or of the "defendant or defendants" against whom recovery is sought. ${ }^{211}$ Thus, in the great majority of states fairly straightforward statutory construction avoided any meaningful analysis of the $49 \%$ or $50 \%$ cutoff point in modified comparative fault.

Four states had modified comparative fault statutes that provided for a comparison of the plaintiff's fault with the fault of "the person" against whom recovery is sought. ${ }^{212}$ The Idaho Supreme Court relied on this language and "fairness" considerations to join Minnesota and Wisconsin in following the single comparison rule. ${ }^{213}$ Colorado relied on slightly different "fairness" considerations to reach the opposite result and adopt the aggregation rule. ${ }^{214}$ In the Idaho case, the plaintiff was $25 \%$ at fault and one defendant was $10 \%$ at fault, while the other defendant was $65 \%$ at fault. ${ }^{215}$ The court noted that if the aggregation rule were followed, the $10 \%$-at-fault defendant could be liable for $75 \%$ of the $25 \%$-at-fault plaintiff's damages, a result the court considered unfair to the $10 \%$-atfault defendant. ${ }^{216}$ The court further noted that, under Idaho's $49 \%$ rule of modified comparative fault, in a case in which the plaintiff and the only defendant were each $50 \%$ at fault, the plaintiff would be barred. ${ }^{217}$ Yet if the plaintiff and the two defendants in a case were each one-third at fault, the aggregation rule would produce the "incongruous" result of permitting the plaintiff to recover two-thirds of his damages even though, again, the plaintiff's fault is equal to, not less than, the fault of each defendant. ${ }^{218}$

Ironically, the Colorado case involved the exact facts used hypothetically three years earlier by the Idaho court-a plaintiff one-

negligence of the defendant or defendants”).

210. See, e.g., ARK. CodE ANN. § 16-64-122 (West 2004 \& Supp. 2010); KAn. STAT. ANN. § 60258a(a) (2005 \& Supp. 2010); see also IND. CODE ANN. § 34-51-2-6 (West 2011) (“all persons”); NEV. ReV. STAT. ANN. § 41.141(1) (West 2005) (“the parties”).

211. See, e.g., N.H. Rev. StAT. AnN. § 507:7-d (2010); 42 PA. Const. StAT. AnN. § 7102(a) (West 2007); see also ARIZ. REV. STAT. ANN. § 12-2506 (2003) ("all persons who contributed to the alleged injury”); UTAH CODE ANN. § 78B-5-818 (West 2009) ("any defendant or group of defendants").

212. See Colo. Rev. Stat. AnN. § 13-21-111(1) (West 2005); IdAHo Code AnN. § 6-801 (West 2006); Minn. Stat. AnN. § 604.01(1) (West 2010); Wis. StAT. AnN. § 895.045 (West 2006).

213. Oldenwalt v. Zaring, 624 P.2d 383, 388 (Idaho 1980).

214. Mountain Mobile Mix v. Gifford, 660 P.2d 883, 890 (Colo. 1983).

215. Odenwalt, 624 P.2d at 384.

216. Under the doctrine of joint and several liability, the plaintiff would be liable for his own $10 \%$ and also for the other defendant's $65 \%$ or $75 \%$ of the total damages. Id. at 387 .

217. Id.

218. Id. 
third at fault and each of the two defendants also one-third at fault. ${ }^{219}$ The court noted that its $49 \%$ rule would allow a $45 \%$-at-fault plaintiff to recover $55 \%$ of his damages from a 55\%-at-fault defendant. ${ }^{220}$ By contrast, if the single comparison rule were adopted, a 20\%-at-fault plaintiff would recover nothing from any of four defendants who were each $20 \%$ at fault. ${ }^{221}$ In the court's opinion, the Colorado legislature enacted the $49 \%$ rule of modified comparative fault to ameliorate the harshness of the old contributory negligence rule, to apportion losses more equitably, but to preserve the principle that "plaintiffs should not recover damages that they caused to themselves."222 Only when the plaintiff's fault exceeds the $49 \%$ or $50 \%$ cutoff point are the damages considered to be damages that the plaintiff caused to himself.

The differing views of fairness derive from how each court approached the application of modified comparative fault to the issue of fairness. The Idaho court viewed the issue through the eyes of a defendant: unfairness is when a defendant would be required to pay damages to a plaintiff who was more at fault than the defendant without regard to the plaintiff's share of the total fault in the case. ${ }^{223}$ The Colorado court viewed the issue through the eyes of a plaintiff: unfairness is when a plaintiff would be barred from recovery despite having been less than $50 \%$ at fault. ${ }^{224}$ The merit of either view of fairness depends on the underlying meaning and importance of the $49 \%$ and $50 \%$ cutoff points, but neither opinion added any persuasive reason for having these cutoff points. ${ }^{225}$

Fortunately, the proposed $83.7 \%$ rule of modified comparative fault completely avoids the problem of choosing between the single comparison rule and the aggregation rule. The $83.7 \%$ rule simply

219. Mountain Mobile Mix, 660 P.2d at 884.

220. Id. at 888 .

221. Id. at 888-89; see also Jensen v. Intermountain Health Care, Inc., 679 P.2d 903, 909-10 (Utah 1984) (posing the same hypothetical situation).

222. Mountain Mobile Mix, 660 P.2d at 888.

223. Under this view, it would be unfair in a $49 \%$ rule state for a $10 \%$-at-fault plaintiff to recover damages from a $10 \%$-at-fault defendant even though the defendants collectively caused $90 \%$ of the total damages.

224. Under this view, it would be unfair in a $50 \%$ rule state to bar a $50 \%$-at-fault plaintiff from recovering damages from a 5\%-at-fault defendant.

225. As courts have noted, the unfairness in certain situations arising under the aggregation rule invariably relates to the legal effects of joint and several liability rather than the legal effects of the aggregation rule. See, e.g., Mountain Mobile Mix, 660 P.2d at 888. One jurist noted that the unfairness derives from the specter of the judgment-proof defendant, which under joint and several liability would burden the solvent defendant with the entire loss. See, e.g., Oldenwalt v. Zaring, 624 P.2d 383, 393-94 (Idaho 1980) (Bistline, J., concurring and dissenting). 
provides that any plaintiff whose fault exceeds $83.7 \%$ of the total fault in the case is completely barred from any recovery. Conversely, any plaintiff whose fault is $83.7 \%$ or less of the total fault may recover a proportionate fault share of his damages. How the remaining fault is divided among the defendants is irrelevant. For example, if the plaintiff is $80 \%$ at fault and the two defendants are each $10 \%$ at fault, the plaintiff may recover $20 \%$ from either of the defendants in a state using joint and several liability or $10 \%$ from each of the defendants in a state using proportionate liability. The plaintiff's fault does not exceed $83.7 \%$ of the total fault, and therefore he is not barred from recovery. ${ }^{226}$

\section{THE BENEFITS OF THE TWO-WAY PROVISION}

The proposed $83.7 \%$ system applies equally to plaintiffs and defendants. $^{227}$ A defendant whose fault exceeds $83.7 \%$ is barred from seeking a comparative fault reduction of the damages based on the minimal fault of the plaintiff in the same manner that the plaintiff whose fault exceeds $83.7 \%$ is barred from any recovery. The rationale is straightforward: any condemnation or punishment of an extremely high level of fault and any insistence upon personal responsibility or accountability for one's actions should apply equally regardless of a party's designation as a plaintiff or a defendant.

In addition, the highly culpable defendant would be jointly and severally liable for any share of fault attributed to another defendant and would be barred from seeking comparative contribution or equitable indemnity from any other defendant. Any other defendant would be less than $16.3 \%$ at fault and thus would be entitled to protection from litigation as a minimally-at-fault party. For example, assume that the plaintiff is $5 \%$ at fault, defendant $A$ is $85 \%$ at fault, defendant $B$ is $10 \%$ at fault, and the total damages are $\$ 100,000$. The plaintiff would be

226. This approach of asking only whether the plaintiff's share of the total fault is above or below the statutory cutoff point is similar to the situation in Illinois, Texas, and Wyoming. In each state's statute creating the $50 \%$ rule of modified comparative negligence, the statute required that the plaintiff's fault be not more than 50\% of the total fault. See 735 ILL. Comp. STAT. ANN. 5/2-1116(c) (West 2003); TEX. CiV. PRAC. \& REM. CODE ANN. § 33.001 (West 2008); Wyo. STAT. ANN. § 1-1109(b) (West 2007). The comparison with a specific fault percentage rather than with the fault of another party or parties renders the choice between the aggregation rule and the separate comparison rule unnecessary.

227. None of the existing modified comparative fault statutes have any provision penalizing the highly culpable defendant. In every modified comparative fault state, the defendant who is $95 \%$ at fault may assert a comparative fault defense for the purpose of reducing his liability by 5\%. See supra note 103 and accompanying text. 
allowed to recover the entire $\$ 100,000$ from defendant $A$. Defendant $A$ would not be allowed to seek comparative contribution or equitable indemnity from defendant $B$.

However, if defendant $A$ is unable to pay all or any of the $\$ 100,000$, the plaintiff should be allowed to maintain a claim against defendant $B$, but only for his proportionate fault share of the damages. Because defendant $A$ will be attributed with the overwhelming majority of the total fault in the case, any fault attributed to either the plaintiff or another defendant would be minor-less than $16.3 \%$. The interest in judicial economy should justify protecting these parties from inappropriate litigation brought by a highly culpable party. On the other hand, judicial economy should not operate to prevent the plaintiff from seeking partial redress from a defendant when the fault of each is minor and the highly culpable defendant cannot satisfy the entire judgment. Thus, in the above example, the 5\%-at-fault plaintiff should be allowed to recover $10 \%$ of his damages, or $\$ 10,000$, from defendant $B$ if defendant $A$ cannot satisfy the judgment. ${ }^{228}$

In one sense, the two-way provision should not be viewed as either unique or unduly burdensome. Under the former all-or-nothing system, a form of a two-way system was developing. As the number of exceptions to the complete bar of contributory negligence kept increasing, defendants were increasingly put in the position of paying the entire cost of accidents in which they were more at fault than the plaintiff. ${ }^{229}$ Imposing the entire cost of an accident on only those defendants whose fault was more than $83.7 \%$ would be far less burdensome on defendants than the rule that was starting to emerge under the all-or-nothing system.

These provisions are rational and consistent. The $83.7 \%$ system is designed to promote judicial economy by imposing slightly disproportionate burdens on the highly culpable party. Nothing in the proposal is intended to burden unnecessarily the minimally at fault parties. One policy rationale developed in the all-or-nothing system was the policy that judicial process should not be available to aid a wrongdoer. ${ }^{230}$ This policy could be readily adapted to the proposed treatment of the highly culpable defendant by indicating that judicial

228. This treatment of the minimally culpable defendant is similar to a provision in a former version of a New Jersey statute applying proportionate liability to any defendant $20 \%$ or less at fault. See N.J. STAT. ANN. § 2A:15-5.3 (1987) (amended 1995). However, unlike the New Jersey statute, the proposed provision is conditional and would apply only if the highly culpable other defendant was unable to pay all of the judgment.

229. See supra Part II.A.

230. See supra note 4. 
process will not be available to aid the highly culpable wrongdoer, whether a plaintiff or a defendant.

Perhaps the most important benefit of the two-way provision is its capacity to motivate conflicting interests in a legislature to compromise on a cutoff number closer to the high end, such as my proposed $83.7 \%$, rather than a number at the low end, such as the $60 \%$ cutoff formerly applicable to strict liability actions in Texas. ${ }^{231}$ In the one-way approach used in all existing modified comparative fault systems, defense interests have nothing to lose by insisting on a number closer to 50\%. With the two-way feature, however, a low cutoff number puts defendant at risk of paying the entire liability in cases in which his fault only slightly exceeds the cutoff number. The risk of paying everything might move states closer to pure comparative fault, but with protection against abuse by highly culpable plaintiffs.

\section{CONCLUSION}

I would not expect any state to adopt my proposed $83.7 \%$ system of modified comparative fault. The $83.7 \%$ number was intentionally chosen to appear totally arbitrary for purposes of a classroom exercise. The number notwithstanding, however, the proposal for a much higher cutoff number-perhaps $75 \%, 80 \%$, or $85 \%$ - governing the reversion to all-or-nothing treatment is far less arbitrary than the existing $49 \%$ or $50 \%$ rules. Those rules have no justification other than a concept of personal responsibility that originated in an earlier era without the option of sharing losses between two negligent parties. The fear of highly culpable plaintiffs bringing claims against minimally culpable defendants is overstated and, in any event, a problem that can be easily cured with less draconian measures, such as a cutoff point well above $50 \%$ but less than $90 \%$.

In addition to the elimination of the discriminatory treatment of parties whose faults are either identical or essentially similar, the proposal provides an equitable option for loss allocation in two-injury accidents that simply does not exist under the existing systems of modified comparative fault. Two-injury highway accidents constitute a significant share of the modern accident problem. It seems unconscionable for the tort system to provide no effective means of allocating those losses equitably. Pure comparative fault would completely solve the problem, but a high cutoff for modified

231. See supra note 30 and accompanying text. 
comparative fault would extend equitable loss allocation to the substantial majority of two-injury cases and impose only a relatively minor distortion of equitable loss allocation on the remaining cases. Finally, the higher cutoff point largely eliminates the need to instruct juries on the legal effects of their fault findings, and it completely eliminates any problem with a comparison of the plaintiff's fault with the fault of multiple tortfeasors.

Finally, the two-way provision provides pressure on defendants to accept the higher cutoff point. Once it is made clear to defendants that the same intolerance of high culpability will be imposed on them as on plaintiffs, I suspect defendants will find a high cutoff point preferable to bearing the entire loss in cases in which they are only slightly more at fault than the plaintiff. 